\title{
Platelet Activating Factor Produced In Vitro by Kaposi's Sarcoma Cells Induces and Sustains In Vivo Angiogenesis
}

\author{
Federico Bussolino, Marco Arese, Giuseppe Montrucchio, " Luca Barra, Luca Primo, Roberto Benelli," Fiorella Sanavio, ${ }^{5}$ \\ Massimo Aglietta, ${ }^{5}$ Dario Ghigo, Marek Rola-Pleszczynski," Amalia Bosia, Adriana Albini, ${ }^{\ddagger}$ and Giovanni Camussi' \\ Dipartimento di Genetica, Biologia e Chimica Medica, and *Dipartimento di Fisiopatologia Clinica, University of Torino, 10126 \\ Torino, Italy; ${ }^{\ddagger}$ Istituto Nazionale per la Ricerca sul Cancro, 16100 Genova, Italy; ${ }^{8}$ Dipartimento di Scienze Biomediche e Oncologia \\ Umana, University of Torino, 10126 Torino, Italy; "Immunology Division, Department of Pediatrics, Faculty of Medicine, University of \\ Sherbrooke, Sherbrooke, Québec, Canada; and 'Cattedra di Nefrologia, II Facoltà di Medicina, University of Pavia, 21100 Varese, Italy
}

\begin{abstract}
Imbalance in the network of soluble mediators may play a pivotal role in the pathogenesis of Kaposi's sarcoma (KS). In this study, we demonstrated that KS cells grown in vitro produced and in part released platelet activating factor (PAF), a powerful lipid mediator of inflammation and cellto-cell communication. IL-1, TNF, and thrombin enhanced the synthesis of PAF. PAF receptor mRNA and specific, high affinity binding site for PAF were present in KS cells. Nanomolar concentration of PAF stimulated the chemotaxis and chemokinesis of $\mathrm{KS}$ cells, endothelial cells, and vascular smooth muscle cells. The migration response to PAF was inhibited by WEB 2170, a hetrazepinoic PAF receptor antagonist. Because neoangiogenesis is essential for the growth and progression of KS and since PAF can activate vascular endothelial cells, we examined the potential role of PAF as an instrumental mediator of angiogenesis associated with KS. Conditioned medium (CM) from KS cells (KS-CM) or $\mathrm{KS}$ cells themselves induced angiogenesis and macrophage recruitment in a murine model in which Matrigel was injected subcutaneously. These effects were inhibited by treating mice with WEB 2170. Synthetic PAF or natural PAF extracted from plasma of patients with classical KS also induced angiogenesis, which in turn was inhibited by WEB 2170. The action of PAF was amplified by expression of other angiogenic factors and chemokines: these included basic and acidic fibroblast growth factor, placental growth factor, vascular endothelial growth factor and its specific receptor $f l k-1$, hepatocyte growth factor, $\mathrm{KC}$, and macrophage inflammatory protein-2. Treatment with WEB 2170 abolished the expression of the transcripts of these molecules within Matrigel containing KS-CM. These results indicate that PAF may cooperate with other angiogenic molecules and chemokines in inducing vascular development in KS. $(J$. Clin. Invest. 1995. 96:940-952.) Key words: HIV • platelet activating factor antagonist $\cdot$ chemokine $\cdot$ growth factor • angiogenesis
\end{abstract}

Address correspondence to Dr. F. Bussolino, Dipartimento di Genetica, Biologia e Chimica Medica, Via Santena 5 Bis., 10126 Torino, Italy. Phone: 11-6706684; FAX: 11-6635663.

Received for publication 15 November 1994 and accepted in revised form 1 May 1995.

J. Clin. Invest.

(C) The American Society for Clinical Investigation, Inc.

0021-9738/95/08/0940/13 $\$ 2.00$

Volume 96, August 1995, 940-952

\section{Introduction}

Kaposi's sarcoma (KS), ${ }^{1}$ once a rarely reported malignancy, is the most common cancer affecting HIV-1-infected individuals. Unlike the more indolent endemic and sporadic form of $\mathrm{KS}$, the disease is usually aggressive and unpredictable in individuals infected by HIV-1, and the neoplasm is the cause of significant morbidity and occasional mortality $(1,2)$. KS is now treated with cytostatic drugs, cytokines, or radiotherapy to control cell proliferation (3-6). Sulfated polysaccharide peptidoglycans control the in vitro growth of KS cells and the in vivo angiogenic response without cytotoxic effect (7).

$\mathrm{KS}$ is composed of spindle-shaped cells, vascular smooth muscle cells (VSMC), endothelial cells (EC), and fibroblasts. The early phase of disease is characterized by an infiltrate of leukocytes and a prominent angiogenesis, which is crucial to the growth and progression of KS (8-12). The current hypothesis to explain the behavior of $\mathrm{KS}$ is an imbalance in the network of soluble mediators caused by HIV-1, other viruses, immunosuppressive treatment, or genetic factors $(13-18)$. The tat transgenic mice develop lesions similar to KS (19), suggesting that this viral protein can be a factor which triggers the imbalance in the network of soluble mediators.

The introduction of routine cell culture of KS-derived spindle cells (20-23) has made it possible to demonstrate that they produce and respond to various soluble mediators $(19,24-30)$. Oncostatin M (27, 28), IL-6 (25), IL-1 (24), and GM-CSF (30), as well as Tat protein (29), stimulate KS cell growth in vitro. Also, KS cells produce factors that stimulate their own chemotactic activity and the proliferation and migration of EC $(31,32)$. Furthermore, KS cells or conditioned medium from $\mathrm{KS}$ cells induces a marked angiogenic response in mice or in chicken chorioallantoic membrane $(33,34)$. Fibroblast growth factor (FGF) (35-38), PDGF (26), vascular endothelial growth factor (VEGF) (39), and hepatocyte growth factor (HGF) (40), produced by KS cells, and other unknown factor(s) (32) have been postulated to be involved in angiogenesis in $\mathrm{KS}$.

Platelet activating factor (PAF) is a phospholipid mediator

1. Abbreviations used in this paper: aFGF, acidic fibroblast growth factor; bFGF, basic fibroblast growth factor; CM, conditioned medium; C-PAF, 1-0-hexadecyl-2- $N$-methylcarbamyl-sn-glycero-3-phosphocholine; EC, endothelial cells; HGF, hepatocyte growth factor; KS, Kaposi's sarcoma; PAF, platelet activating factor; PAF-R, PAF receptor; RT, reverse transcriptase; $(S)$-PAF, 1-O-octadecyl-2-acetyl- $(S)$ glycero-3-phosphocholine; Thr, thrombin; VEGF, vascular endothelial growth factor; VSMC, vascular smooth muscle cells. 
of inflammation and cell-to-cell communications that belongs to the structurally related family of acetylated phosphoglycerides (for reviews see references 41-43). PAF is produced by stimulated inflammatory cells (for reviews see references 41 43), EC (44-48), and T cells (49) and acts through a G protein-coupled receptor, which has been cloned recently ( 50 , 51 ). PAF possesses pleiotropic activities at nanomolar concentrations, including platelet activation, contraction of smooth muscle, chemotaxis and granule secretion of neutrophils and macrophages, and synthesis of IL-1 and TNF by macrophages (for reviews see references 41-43). Also VSMC (52) and EC are relevant targets for PAF (53-55). PAF activates EC, modifying their adhesive properties for circulating cells (56) and inducing rearrangement of cytoskeletal structure $(53,55)$.

The aim of this study was to evaluate whether KS cells can produce and respond to PAF. The results obtained indicate that PAF is synthesized by KS cells and that it is instrumental in the in vitro migration of $\mathrm{KS}$ cells and the in vivo angiogenic response.

\section{Methods}

Materials. 1-O-octadecyl-2-acetyl-( $R$ )-glycero-3-phosphocholine (PAF), 1-O-octadecyl-2-lyso-sn-glycero-3-phosphocholine, and PDGF were from Bachem Feinkemikalien (Bubendorf, Switzerland); 1-0-hexadecyl-2- $N$-methylcarbamyl-sn-glycero-3-phosphocholine (C-PAF) was from Cascade Biochem Ltd. (Berkshire, United Kingdom); 1-O- $\left[{ }^{3} \mathrm{H}\right]-$ octadecyl-2-acetyl-sn-glycero-3-phosphocholine $(130 \mathrm{Ci} / \mathrm{mmol})$ and $\left[\alpha{ }^{32} \mathrm{P}\right] \mathrm{dCTP}(3,000 \mathrm{Ci} / \mathrm{mmol})$ were from Amersham International (Buckinghamshire, United Kingdom); IL- $1 \alpha$ and oncostatin $M$ were from Immunex (Seattle, WA); TNF was from Genentech, Inc. (South, San Francisco, CA); WEB 2170 (8-(-)6-(2-chlorophenyl)-8,9 dihydro-1-methyl-8 [(4-morpholinyl)carbonyl]-4H, 7H-cyclopenta[4,5] thieno[3,2,-f][4,3-a][1,4]diazepine) was from Boehringer Ingelheim (Ingelheim, Germany) and its purity, detected by TLC and HPLC, was $>$ 99\%; Matrigel was from Collaborative Research Inc. (Bedford, MA); mAbs anti-L3, anti-Ly2, and anti-Mac-1 conjugated with fluorescein were purchased from Cederlane (Ontario, Canada); rabbit polyclonal antibody anti- $f l k-1$ (raised against a glutathione-S-transferase fusion protein containing $f(k-1$ sequence corresponding to amino acids 1,158 1,345 , carboxy terminal) and rabbit polyclonal antibody anti-VEGF (raised against amino acids 1-20, amino terminal) were from SantaCruz Biotechnology (Santa Cruz, CA); TLC plates were from Merck (Darmstadt, Germany); FCS was from Irvine Scientific (Santa Ana, CA); Ultroser HY was from IBF Biotechnics (Villeneuve-le Garenne, France); plastic material and products for cell culture were from Costar Italia (Milano, Italia) and GIBCO-BRL (Paisley, United Kingdom), respectively. 1-O-octadecyl-2-acetyl-( $S$ )-glycero-3-phosphocholine $[(S)$-PAF] and basic FGF (bFGF) were obtained through the courtesy of Dr. G. Ostermann (Erfurt, Germany) and Dr. F. Bertolero (Pharmacia-Farmitalia-Carlo Erba, Milano, Italy), respectively. A polyclonal antibody anti-bFGF was generated in the laboratory of Dr. D. Rifkin (New York University, New York) and obtained through the courtesy of Dr. M. Presta (University of Brescia, Brescia, Italy). A rabbit polyclonal antibody anti-synthetic peptide corresponding to the PAF-receptor (PAF-R) residues 164-173 has been characterized previously (57). Reagents used in reverse transcriptase (RT)-PCR and to prepare mRNA were from GIBCO-BRL and Stratagene (La Jolla, CA). Other reagents and solvents Analar grade were from Sigma Chemical Co. (St. Louis, MO)

For the in vitro and in vivo experiments, PAF, $(S)$-PAF, C-PAF, and 1-O- $\left[{ }^{3} \mathrm{H}\right]$ octadecyl-2-acetyl-sn-glycero-3-phosphocholine were purified by TLC and HPLC (46) and did not contain detectable contaminants.

Cells. Cultures of KS-derived cells were established from cutaneous biopsies of two HIV-seropositive patients and one patient with a sporadic form of KS (HIV negative) and maintained as described previously (23). The cultures were named AIDS-IST-KS3, AIDS-IST-KS4, ISTKS8, and AIDS-IST-KS11, respectively (abbreviated to KS3, KS4, $\mathrm{KS} 8$, and KS11). Cells had the elongated morphological aspect typical of spindle-shaped KS cells $(20-22,25)$; immunohistochemical characterization showed positivity for vimentin, collagen I, laminin, smooth muscle actin, and desmin, but not for CD45, von Willebrand factor, and EN4 antigen, in agreement with previous reports $(20,25,58,59)$ and as already described (23). Cells were grown on plastic surface coated with gelatin in RPMI 1640 containing 20\% FCS supplemented with amino acids and $0.5 \%$ Ultroser HY. Cultures were used at passages 4 15 , and the day before the experiments $50 \%$ of medium was renewed.

EC from human umbilical cord vein were prepared, grown, and characterized as described previously $(46,60)$. Human myelomonocytic U937 cells and human megakaryoblastic M07 cells were maintained in RPMI 1640 medium with $10 \%$ FCS (a gift of Dr. L. Pegoraro, Torino, Italy). Human VSMC (kind gift from Dr. M. Trovati, Torino. Italy), J774 murine macrophage cell line, and MDCK cells were maintained in DME containing $10 \% \mathrm{FCS}, 10 \mathrm{mM}$ Hepes, and $10 \mathrm{mM} \mathrm{N}$-Tris(hydroxymethyl) methyl-2-aminoethanesulfonic acid ( $\mathrm{pH}$ 7.4). Human PMN were prepared as described previously (61).

Conditioned medium (CM) was prepared from KS (KS-CM) as follows: cells were grown to confluence in $150-\mathrm{cm}^{2}$ dishes and then incubated for $48 \mathrm{~h}$ with Iscove's medium containing $0.45 \% \mathrm{BSA}$ (LPSfree) (GIBCO-BRL). CM from EC (EC-CM) was prepared as above, but Iscove's medium also contained $6 \mathrm{mg} /$ liter transferrin, $5 \mathrm{mg} / \mathrm{liter}$ insulin, $100 \mathrm{mg} /$ liter soybean lecithin, and $6.73 \mathrm{mg} /$ liter sodium selenite. CM from J774, MDCK, and M07 cell lines and VSMC were prepared in a similar way in Iscove's medium. The cell viability assessed by trypan blue exclusion was $>90 \%$. The medium was centrifuged and used immediately or 10-fold-concentrated by a sterilized Centricon 10 filter (Amicon, Inc., Beverly, MA) precoated with $0.25 \%$ BSA (LPSfree) solution and stored at $-80^{\circ} \mathrm{C}$.

$P A F$ production. $\mathrm{KS}$ cells grown to confluence on $35-\mathrm{mm}$-diameter Petri dishes $\left(3 \times 10^{4} / \mathrm{cm}^{2}\right)$ were washed twice with RPMI 1640 medium containing $20 \mathrm{mM}$ Hepes ( $\mathrm{pH} 7.4$ ) and $0.25 \%$ BSA (LPS-free) and incubated in $5 \% \mathrm{CO}_{2}$ for the indicated times with different concentrations of human recombinant IL-l $\alpha$, TNF- $\alpha$, and thrombin (Thr). PAF released into the medium and cell-associated PAF was extracted, purified by TLC, and measured by washed rabbit platelet aggregation as described $(44,46,61)$. PAF was also extracted, purified, and quantified from the plasma (62) of two Caucasian subjects affected by classic $\mathrm{KS}$ and the amounts detected were 0.7 and $1.3 \mathrm{pmol} / \mathrm{ml}$, respectively. Biologically active PAF has been characterized on the basis of its physicochemical and chromatographic characteristics and sensitivity to lipases $(44,46,61,62)$.

Binding assay. For binding studies, cell monolayers (in 12-well plates) were put on ice, rinsed four times with prechilled RPMI 1640 medium containing $20 \mathrm{mM}$ Hepes, $\mathrm{pH} 7.4,0.1 \%$ BSA, $100 \mu \mathrm{g} / \mathrm{ml}$ soybean trypsin inhibitor, and bacitracin (binding medium), and incubated with different concentrations of $\left[{ }^{3} \mathrm{H}\right] \mathrm{PAF}$ in the presence of 200fold excess of cold ligand at $4^{\circ} \mathrm{C}$ for $3 \mathrm{~h}$ in a final volume of $600 \mu \mathrm{l} /$ well. The monolayers were then washed five times with the binding medium and extracted with 2\% SDS in PBS. The extracts were then counted in a Packard $\gamma$-counter. Specific binding-calculated by subtracting, from the total counts per minute, the counts per minute bound after incubation with 200 -fold excess of unlabeled ligand-was $\sim 80 \%$. The $K_{\mathrm{d}}$ was estimated by Scatchard plot analysis using the Ligand program (Elsevier-Biosoft, Cambridge, United Kingdom).

Chemotaxis assay. Chemotaxis assays were performed as described previously (60) using the Boyden chamber technique. Polycarbonate filters (5- $\mu \mathrm{m}$ pore size, polyvinylpyrrolidone-free; Nucleopore Corp., Pleasanton, CA) were coated with gelatin (Difco Laboratories, Detroit, MI) $(0.1 \%$ for $6 \mathrm{~h}$ at room temperature). Chemotactic agents in specific medium used to culture KS cells, EC, VSMC, and J774 cells supplemented with $0.25 \%$ BSA (LPS-free) were placed in the lower compart- 
ment of the chamber, and $2 \times 10^{5}$ suspended cells in medium containing $1 \%$ FCS were then seeded in the upper compartments. After $6 \mathrm{~h}$ of incubation at $37^{\circ} \mathrm{C}$, the upper surface of the filter was scraped with a rubber policeman. The filters were fixed and stained with Diff-Quick (Harleco, Gibbstown, NJ), and 10 oil immersion fields were counted after coding samples.

The directness of PAF-stimulated migration was evaluated using checkerboard analysis (63). Increasing concentrations of PAF were placed in both top and bottom wells of the Boyden chamber to establish positive, absent, or negative concentration gradients across the filter barrier. Directed locomotion, chemotaxis, is the response to a net gradient of attractant; random stimulated migration, chemokinesis, is the response to attractant when no concentration gradient is present.

Cell growth assay. $1.5 \times 10^{3}$ cells were plated in 96-well plates coated with gelatin in specific growth medium indicated above. After $24 \mathrm{~h}$, the medium was removed and replaced with specific medium containing $2.5 \%$ FCS. Stimuli indicated in Results were added at days $0,2,4$, and 6 and cell number was estimated at day 8 by a colorimetric method as detailed previously (60). Proportionality between absorbance and cell counts existed up to $6.5 \times 10^{4} \mathrm{KS}$ cells, $8.0 \times 10^{4} \mathrm{EC}$, and 9 $\times 10^{4}$ VSMC.

Murine angiogenesis assay. Female DBA/2 mice (Charles River, Calco (CO) Italy) were used at 6-8 wk of age. Angiogenesis was assayed as growth of blood vessels from subcutaneous tissue into a solid gel of Matrigel containing the test sample (64). Matrigel $(8.1 \mathrm{mg} / \mathrm{ml})$ in liquid form at $4^{\circ} \mathrm{C}$ was mixed with the experimental substances in the presence of $64 \mathrm{U} / \mathrm{ml}$ heparin and injected $(0.5 \mathrm{ml})$ into the abdominal subcutaneous tissue of mice along the peritoneal midline. Matrigel rapidly forms a solid gel at body temperature, trapping the factors to allow slow release and prolonged exposure to surrounding tissues. At various times, mice were subsequently killed and gels were recovered and processed for histology. Part of the tissue was fixed in 10\% buffered formalin and embedded in paraffin. Sections cut at $3 \mu \mathrm{m}$ and stained with hematoxylin and eosin were studied by light microscopy. Other sections, obtained from frozen tissue cut with a cryostat, were processed for immunofluorescence as described previously (65). Vessel area and the total Matrigel area were planimetrically assessed from stained sections as described (65). Only those structures possessing a patent lumen lined by EC were considered as vessels. Results were expressed as percentage \pm SD of the vessel area to the total Matrigel area.

Angiogenesis was evaluated at different time intervals using the following as agonists: KS-CM, EC-CM, CM prepared from VSMC, J774, M07 and MDCK cell lines, (R)PAF and its analogues, native PAF extracted from a patient with classical KS (a 71-yr-old Caucasian male, with clinical and histologic diagnosis of classical KS with extended cutaneous lesions), and KS cells. In selected animals, WEB 2170, a PAF-R antagonist (66), dissolved in PBS, was included in the Matrigel plug or injected intraperitoneally for the time of experiment. Treatment of animals with WEB 2170 did not induce acute (death, ataxia, depression, trembling) or chronic (reduction of weight, reduction of consumption of water and food, modification of general condition) signs of toxicity.

$R T$-PCR analysis. Total RNA extracted by the guanidine isothiocyanate/cesium chloride method (67) was obtained from KS cells, human PMN, and the U937 cell line to study the expression of PAF-R and transcripts, and from Matrigel plugs to study the expression of chemokines and angiogenic growth factors. $2 \mu \mathrm{g}$ of total RNA was denatured by heating and reverse transcribed by $20 \mathrm{U}$ Moloney murine leukemia virus RT into first strand cDNA using 25 pmol of primers $(\mathrm{dt})_{15}$. The reaction was carried out for $1 \mathrm{~h}$ at $37^{\circ} \mathrm{C}$ in a $20-\mu \mathrm{l}$ final volume containing $5 \mathrm{mM}$ DTT, $40 \mathrm{U}$ RNAsin, $5 \mathrm{mM}$ dNTPs mixture, and $5 \times$ buffer ( $200 \mathrm{mM}$ Tris, $\mathrm{pH} 8.3,40 \mathrm{mM} \mathrm{MgCl}$ ). PCR was performed in a DNA thermal cycler (Perkin-Elmer Cetus Corp., Norwalk, CT) using $5 \mu \mathrm{l}$ of the transcription mixture and $2.5 \mathrm{U}$ of Taq polymerase. dNTPs (0.2 mM), 10× reaction buffer $(100 \mathrm{mM}$ Tris- $\mathrm{HCl}, \mathrm{pH} 8.3,50 \mathrm{mM}$ $\mathrm{KCl}, 15 \mathrm{mM} \mathrm{MgCl}_{2}, 0.01 \%$ gelatin), and $35 \mathrm{pmol}$ of each primer were added in a $50-\mu \mathrm{l}$ reaction volume. The following specific oligomers
(Tib Molbiol Berlin GmbH, Berlin, Germany) were used: PAF-R (51), sense: 5' CATCTGCTTCGTGCCCCA 3', antisense: 5' CGGTGAGGTGCTTGCGGA $3^{\prime}$; murine VEGF (68), sense: $5^{\prime}$ ggATCCATgAACTTTCTgCT $3^{\prime}$, antisense: 5' gAATTCACCgCCTCggCTTgTC 3'; JE (69), sense: 5' CCTgCTgCTACTCATTCA 3', antisense: 5' ATTTACgggTCAACTTCA $3^{\prime}$; murine HGF (70), sense: $5^{\prime}$ TgCCCTATTTCCCgTTgT 3', antisense: 5' TTCTCCTCgCCTCTCTCA 3'; murine MIP-2 (71), sense: 5' gCCAgTgAACTgCgCTgTCAATgC 3', antisense: 5' gTTAgCCTTgCCTTTgTTCAgTATC 3'; KC (72), sense: 5' gCCAATgAgCTgCgCTgTCAATgC 3', antisense: 5' CTTggggACACCTTTTAgCATCTT $3^{\prime}$; murine PIGF, sense: 5' CAgCCAACATCACTATgCAg 3', antisense: 5' gggTgACggTAATAAATACg 3'; murine bFGF (73), sense: 5' TGCGCATCCATC $3{ }^{\prime}$, antisense: 5' CCGGTCACGGAA 3'; murine acidic FGF (aFGF) (73), sense: 5' AGCGACCAGCACATTCAG 3', antisense: 5' TCCCGTTCTTCTTGAGGC 3'; murine FGF-3 (74), sense: 5' ACGCAGAGTGTGAGTTTGTG 3'', antisense: 5' AGGAAGAGAGAGGACTTTTGT 3'; murine K-FGF (73), sense: 5' GCAGACACGAGGGACAG 3', antisense: 5' CCGCCCGTTCTTACTG 3'; murine FGF-5 (73), sense: 5' TCAGGGGATTGTAGGAATACG 3', antisense: 5' GTAGGAAGTGGGTGGAGAC 3'; murine FGF-6 (75), sense: 5' CAGGCTCTCGTCTTCTTAG 3', antisense: 5' ATTCACACCCGAAATCTCTC 3'; murine FGF-7 (EMBL accession number Z22703), sense: 5' TCCTGCCAACTCTGCTCTAC 3', antisense: 5' acttgcctcgtttgtcaat 3'

The PCR protocol for PAF-R, MIP-2, FGF-7, and KC cDNAs was as follows: $1 \mathrm{~min}$ at $94^{\circ} \mathrm{C}, 1 \mathrm{~min}$ at $55^{\circ} \mathrm{C}, 1 \mathrm{~min}$ at $72^{\circ} \mathrm{C}$ for 30 cycles; $1 \mathrm{~min}$ at $94^{\circ} \mathrm{C}, 1 \mathrm{~min}$ at $55^{\circ} \mathrm{C}, 10 \mathrm{~min}$ at $72^{\circ} \mathrm{C}$ for the last cycle. For PIGF, K-FGF, FGF-6, and HGF cDNAs the PCR protocol was as follows: 1 min at $94^{\circ} \mathrm{C}, 1 \mathrm{~min}$ at $50^{\circ} \mathrm{C}, 1 \mathrm{~min}$ at $72^{\circ} \mathrm{C}$ for 30 cycles; $1 \mathrm{~min}$ at $94^{\circ} \mathrm{C}$, $1 \mathrm{~min}$ at $50^{\circ} \mathrm{C}, 10 \mathrm{~min}$ at $72^{\circ} \mathrm{C}$ for the last cycle. For VEGF and FGF5 cDNAs the PCR protocol was as follows: $1 \mathrm{~min}$ at $94^{\circ} \mathrm{C}, 2 \mathrm{~min}$ at $55^{\circ} \mathrm{C}, 3 \mathrm{~min}$ at $72^{\circ} \mathrm{C}$ for 30 cycles; $1 \mathrm{~min}$ at $94^{\circ} \mathrm{C}, 2 \mathrm{~min}$ at $55^{\circ} \mathrm{C}, 10$ min at $72^{\circ} \mathrm{C}$ for the last cycle. For JE and FGF-3 cDNAs the PCR protocol was as follows: $1 \mathrm{~min}$ at $94^{\circ} \mathrm{C}, 1 \mathrm{~min}$ at $45^{\circ} \mathrm{C}, 1 \mathrm{~min}$ at $72^{\circ} \mathrm{C}$ for 30 cycles; $1 \mathrm{~min}$ at $94^{\circ} \mathrm{C}, 1 \mathrm{~min}$ at $45^{\circ} \mathrm{C}, 10 \mathrm{~min}$ at $72^{\circ} \mathrm{C}$ for the last cycle. For aFGF and bFGF cDNAs the PCR protocol was as follows: $1 \mathrm{~min}$ at $94^{\circ} \mathrm{C}, 1 \mathrm{~min}$ at $55^{\circ} \mathrm{C}, 1 \mathrm{~min}$ at $72^{\circ} \mathrm{C}$ for 35 cycles; $1 \mathrm{~min}$ at $94^{\circ} \mathrm{C}, 1 \mathrm{~min}$ at $55^{\circ} \mathrm{C}, 10 \mathrm{~min}$ at $72^{\circ} \mathrm{C}$ for the last cycle. RT-PCR of $\beta$ actin was performed by using specific oligonucleotides (Stratagene) with the following protocol: $1 \mathrm{~min}$ at $94^{\circ} \mathrm{C}, 1 \mathrm{~min}$ at $55^{\circ} \mathrm{C}, 1 \mathrm{~min}$ at $72^{\circ} \mathrm{C}$ for 30 cycles; $1 \mathrm{~min}$ at $94^{\circ} \mathrm{C}, 1 \mathrm{~min}$ at $55^{\circ} \mathrm{C}, 10 \mathrm{~min}$ at $72^{\circ} \mathrm{C}$ for the last cycle. $20 \mu \mathrm{l}$ of the amplified solution was run in a $1.8 \%$ agarose gel electrophoresis in Tris-borate-EDTA buffer and stained with $0.5 \mu \mathrm{g} /$ $\mathrm{ml}$ ethidium bromide. The products of PCR were analyzed and identified by Southern blot analysis, except those of FGF-7. Specific cDNAs were labeled with $\left[\alpha-{ }^{32} \mathrm{P}\right] \mathrm{dCTP}(3,000 \mathrm{Ci} / \mathrm{mmol}$; Amersham International $)$ at $2.2 \times 10^{8} \mathrm{cpm} / \mu \mathrm{g}$ specific activity, by the random primer labeling method (Megaprime DNA labeling system; Amersham International) according to the manufacturer's instructions. The gel was washed for $10 \min$ in $0.5 \mathrm{M} \mathrm{NaOH}+1.5 \mathrm{M} \mathrm{NaCl}, 10 \min$ in $0.5 \mathrm{M}$ Tris (pH 7.5) $+1.5 \mathrm{M} \mathrm{NaCl}$ and then blotted on a nylon Duralon-UV membrane. The membrane was prehybridized for $2 \mathrm{~h}$ and hybridized overnight at $57^{\circ} \mathrm{C}$ in a solution containing $5 \times$ Denhardt's, $6 \times$ SSC, $10 \%$ SDS, and $100 \mu \mathrm{g} / \mathrm{ml}$ denatured salmon sperm DNA. Washes were carried out at high stringency $\left(2 \times \mathrm{SSC}+0.1 \% \mathrm{SDS}\right.$ at $20^{\circ} \mathrm{C}$ for $30 \mathrm{~min}, 0.5 \times \mathrm{SSC}$ $+0.1 \%$ SDS at $57^{\circ} \mathrm{C}$ for $30 \mathrm{~min}$, and three times in $0.1 \times \mathrm{SSC}+0.1 \%$ SDS at $57^{\circ} \mathrm{C}$ for $30 \mathrm{~min}$ ) and the membrane was exposed to Hyperfilm MP (Amersham International) with intensifying screens at $-80^{\circ} \mathrm{C}$ for $3 \mathrm{~d}$.

\section{Results}

Production of PAF by KS cells. The three KS cell lines studied produced a small quantity of PAF that, in short-term experiments, remained associated with the cells (Fig. 1). However, when PAF was measured after $48 \mathrm{~h}$ of growth without FCS in 

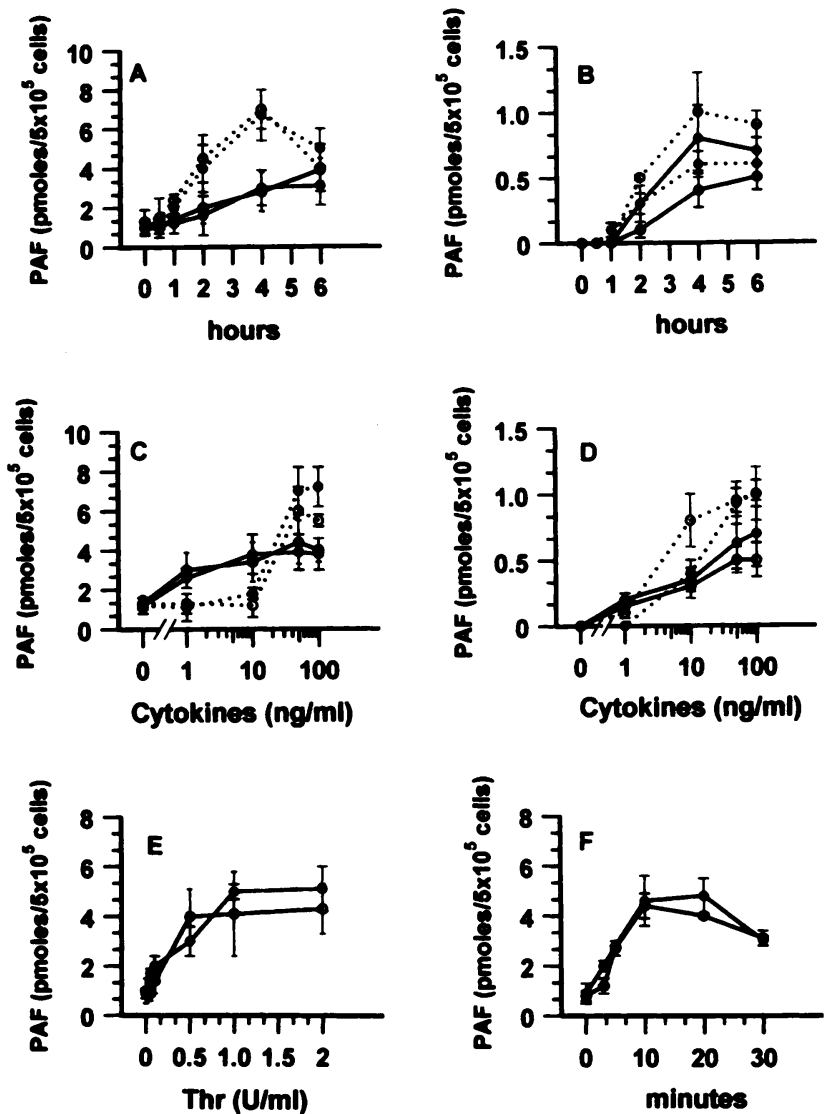

Figure 1. Synthesis and release of PAF by KS cells. KS3 (open circles) and KS4 cells (closed circles) were grown at confluence on 35-mmdiameter dishes, washed twice, and then stimulated in Iscove's medium containing $0.25 \%$ BSA with IL- $1 \alpha$ (solid lines), TNF (dotted lines) $(A-D)$, or Thr $(E$ and $F) . A$ and $B$ : time course of PAF synthesis $(A)$ and release $(B)$ of PAF elicited by cytokines $(50 \mathrm{ng} / \mathrm{ml}) . C$ and $D$ : dose dependence of synthesis $(C)$ and release $(D)$ of PAF by cells treated for 4 and $6 \mathrm{~h}$ with different concentrations of TNF and IL-1 $\alpha$, respectively. $E$ : dose dependence of PAF synthesis by cells stimulated with Thr. $F$ : time course of the stimulation with $\mathrm{Thr}(1 \mathrm{U} / \mathrm{ml})$. Mean $\pm S D$ of three duplicate experiments. Similar results have been obtained on .KS8 cells.

$\mathrm{CM}$, the amount of mediator released spontaneously was $9.3 \pm 0.4,12.5 \pm 0.6$, and $8.8 \pm 1.0 \mathrm{pmol} / 5 \times 10^{6}$ cells $/ 48 \mathrm{~h}$. $(n$ $=5$ ), respectively, in KS3, KS4, and KS8 cells. TNF and IL$1 \alpha$ increased PAF synthesis by KS cells (Fig. 1), and $\sim 20 \%$ was released. Cytokines activated in a dose-dependent manner (Fig. 1, $C$ and $D$ ) a delayed PAF synthesis, reaching a plateau after 4-6 h. (Fig. 1, $A$ and $B$ ). Thr induced in a dose-dependent manner a rapid PAF production, which was not followed by detectable release (Fig. 1, $E$ and $F$ ).

Effects of PAF on KS cells, EC, VSMC, and J774 cell line. $\mathrm{EC}$, VSMC, macrophages, and the KS spindle cells are commonly present in KS lesion (8-12). We thus studied the effect of PAF on the migration and proliferation of KS cells, EC, VSMC, and macrophage murine cell line J774. PAF promoted in a dose-dependent manner the motility of KS cells, EC, VSMC, and J774 cells in the Boyden chamber. The motility response of three different cell types was maximal at PAF con-
Table I. Effects of PAF and Its Analogues on EC, VSMC, and J774 Cell Motility

\begin{tabular}{|c|c|c|c|}
\hline & \multicolumn{3}{|c|}{ Number of migrated cells } \\
\hline & EC & VSMC & J774 \\
\hline Control & $15 \pm 6^{*}$ & $8 \pm 3$ & $20 \pm 6$ \\
\hline Fibrinogen $(1 \mathrm{mg} / \mathrm{ml})$ & $106 \pm 31$ & Not tested & Not tested \\
\hline PDGF (20 ng/ml) & Not tested & $60 \pm 8$ & Not tested \\
\hline \multicolumn{4}{|l|}{ PAF } \\
\hline $0.1 \mathrm{nM}$ & $18 \pm 6$ & $10 \pm 4$ & $18 \pm 9$ \\
\hline $1 \mathrm{nM}$ & $23 \pm 8$ & $13 \pm 5$ & $19 \pm 11$ \\
\hline $10 \mathrm{nM}$ & $38 \pm 10$ & $24 \pm 9$ & $25.8 \pm 7$ \\
\hline $20 \mathrm{nM}$ & $45 \pm 7$ & $39 \pm 10$ & $38 \pm 10$ \\
\hline $50 \mathrm{nM}$ & $61 \pm 12$ & $41 \pm 8$ & $68 \pm 12$ \\
\hline $100 \mathrm{nM}$ & $66 \pm 18$ & $35 \pm 7$ & $73 \pm 7$ \\
\hline$(S)$ PAF $50 \mathrm{nM}$ & $12 \pm 9$ & $5 \pm 2$ & Not tested \\
\hline Lyso-PAF $100 \mathrm{nM}$ & $18 \pm 9$ & $10 \pm 6$ & $21 \pm 7$ \\
\hline WEB $217050 \mu \mathrm{M}$ & $12 \pm 4$ & $9 \pm 3$ & $19 \pm 7$ \\
\hline PAF $50 \mathrm{nM}+$ WEB $21701 \mu \mathrm{M}$ & $56 \pm 5$ & $44 \pm 6$ & Not tested \\
\hline (R)PAF $50 \mathrm{nM}$ + WEB $217010 \mu \mathrm{M}$ & $40 \pm 7$ & $36 \pm 6$ & $35 \pm 11$ \\
\hline PAF $50 \mathrm{nM}+$ WEB $217020 \mu \mathrm{M}$ & $23 \pm 6$ & $18 \pm 7$ & $24 \pm 16$ \\
\hline PAF $50 \mathrm{nM}+$ WEB $217050 \mu \mathrm{M}$ & $16 \pm 8$ & $12 \pm 6$ & $11 \pm 5$ \\
\hline
\end{tabular}

Migration assay was performed by the Boyden chamber technique as described in Methods by adding chemotactic agents to the lower compartment of the chamber, and $2 \times 10^{5}$ cells $/ 0.2 \mathrm{ml}$ with or without WEB 2170 were seeded in the upper compartment. Cells migrated after $6 \mathrm{~h}$ of incubation to the lower surface of the filter were counted after coding samples. * The numbers are the mean \pm SD of three fields $(\times 100)$ counted, in a representative experiment out of four.

centrations ranging from 10 to $50 \mathrm{nM}$ (Fig. 2 and Table I). $(S)$-PAF (Fig. 2) and lyso-PAF were ineffective (Table I). In checkerboard experiments, maximal induction of migration across filters occurred in the presence of a positive concentration gradient between the lower and the upper compartments of the chamber. With equal concentrations of PAF above and below the filter, a smaller but significant enhancement of migration of $\mathrm{KS}$ cells, EC, and VSMC was observed, suggesting that there is a chemokinetic component, in addition to chemotaxis, in the action of PAF on locomotion of these cell types (Table II). In contrast, PAF did not promote chemokinesis of J774 cells ( Table II). WEB 2170, a PAF-R antagonist, inhibited the migratory effect of PAF in a dose-dependent manner (Fig. 2). WEB 2170 also reduced the motility induced by $\mathrm{KS}-\mathrm{CM}$ and by natural PAF extracted from KS-CM tested on KS, EC, and J774 cells, suggesting that the PAF present in KS-CM was biologically active (Table III). However, when KS-CM was used as a stimulus, the inhibitory effect of WEB 2170 was more evident on EC, VSMC, and J774 cells than on KS cells (Table III).

Since cell proliferation was studied in the presence of FCS, C-PAF, which is resistant to inactivation by acetylhydrolase (76), was used. C-PAF did not modify the basal growth of KS cells, EC, VSMC (Table IV), and $\mathbf{J 7 7 4}$ cells (not shown).

Expression of PAF-R in KS cells. Monolayers of KS cells were incubated with increasing concentrations of $\left[{ }^{3} \mathrm{H}\right] \mathrm{PAF}$ in the presence of 200 -fold excess of unlabeled ligand. The direct binding curves indicate that PAF binding to KS cells reached saturability (Fig. $2 \mathrm{~A}$ ). Scatchard analysis indicated the presence of one class of binding sites and the resulting $K_{\mathrm{d}}$ was 128 (Fig. 2 B), 98, and $140 \mathrm{pM}$, respectively, for KS3, KS4, and KS8 cells. The number of receptors per cell ranged from 450 (Fig. $2 \mathrm{~B}$ ) to 880 in the three lines studied. 




C

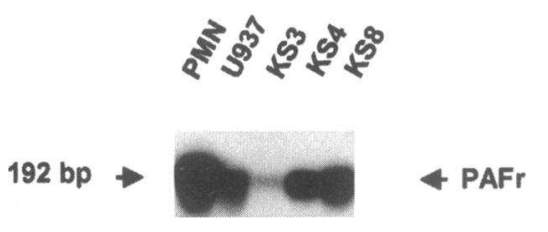

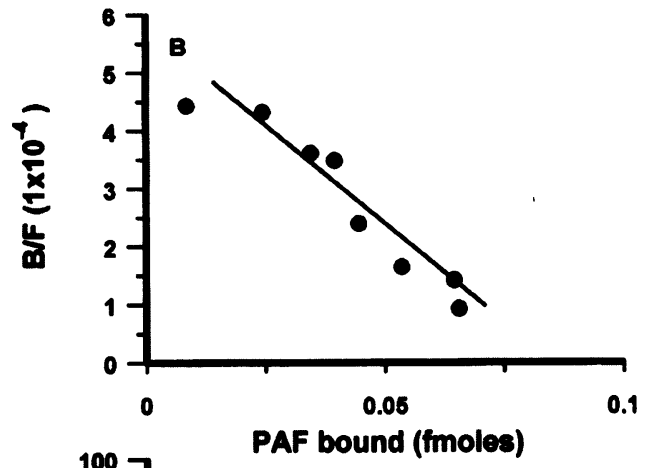

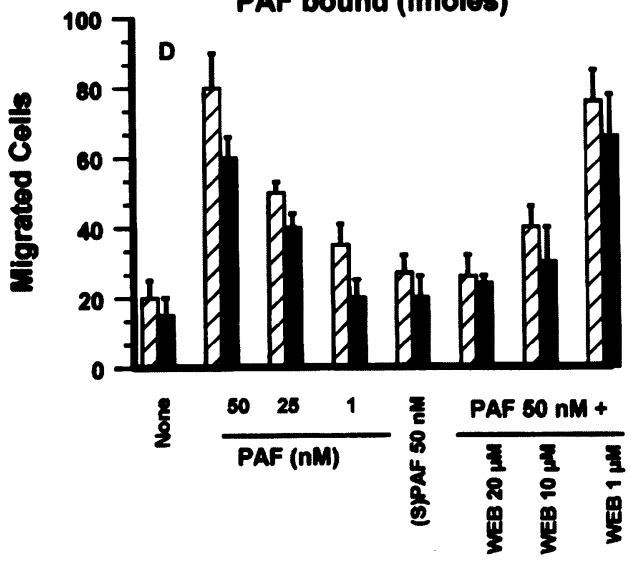

Figure 2. Expression and activation of PAF-R in KS cells. $(A)$ Specific $\left[{ }^{3} \mathrm{H}\right]$ PAF ligand binding curve to KS3 line. (B) Scatchard analysis of data presented in $A$. (C) Detection of PAF-R mRNA by PCR. RNA was reverse transcribed and amplified (24). The figure shows the identification of PCR products by Southern blot done with specific cDNA. U937 cells and PMN were used as positive control. $(D)$ Migration of KS3 (hatched bar) and KS4 (black bar) induced by PAF of its enantiomer $(S)$ PAF in the absence or presence of WEB 2170. Mean $\pm S D$ of migrated cells counted per field for triplicate determinations of one experiment out of three. Similar results have been obtained with KS8 cells.
We examined also the capacity of confluent $\mathrm{KS}$ cells to express the specific transcript of PAF-R. RNA extracted from $\mathrm{KS}$ cells as well as from PMN and U937 cells, used as positive controls, was analyzed by RT-PCR using specific primers for PAF-R. Amplification of RNA extracted from KS cells and positive controls gave a band of $192 \mathrm{bp}$, which corresponds to the selected region of the PAF-R-cDNA (51) and was identified by Southern blot (Fig. $2 C$ ).

Role of PAF in angiogenesis induced by $K S-C M$ and $K S$ cells. Matrigel containing KS-CM was injected subcutaneously into mice, and the histologic and morphometric analysis of the plugs was performed on days 2, 5, 7, and 8 (Figs. 3 and 4).

KS-CM had angiogenic activity in $83 \%$ of animals ( 10 positive implants out of $12 ; P<0.001$ by Fisher exact test) with the maximal vascularization scored at day 7 (Fig. $4 \mathrm{~A}$ ). $\mathrm{CM}$ from EC (Fig. $4 B$ ), from VSMC, and from M07 and MDCK cell lines (not shown) did not induce angiogenesis. CM prepared from J774 cells had a little angiogenic effect (percentage vascularized: control: 72 ; CM: $134 ; n=3$ ), which was not blocked by the PAF receptor antagonist WEB 2187. Also, KS cells implanted into Matrigel promoted an angiogenic response (Fig. 4 B).

KS-CM induced penetration of von Willebrand factor-positive EC into the Matrigel (Fig. 5). Canalization of vessels progressively increased in the following days with formation of linear or microaneurismatic structures containing circulating cells (Fig. $5 \mathrm{~B}$ ). An infiltration of macrophages (Mac-1-positive cells) was evident at day 2 (Table $V$ ) and reached the maximum at day 7 (Fig. $5 E$ and Table V) with few L3- or Ly2-positive lymphocytes. The angiogenic effect of KS-CM was prevented by WEB 2170 in a dose-dependent manner (Table VI). When WEB 2170 was added together with KS-CM or

Table II. Checkerboard Analysis of PAF-induced Migration of KS Cells, EC, VSMC, and J774 Cells

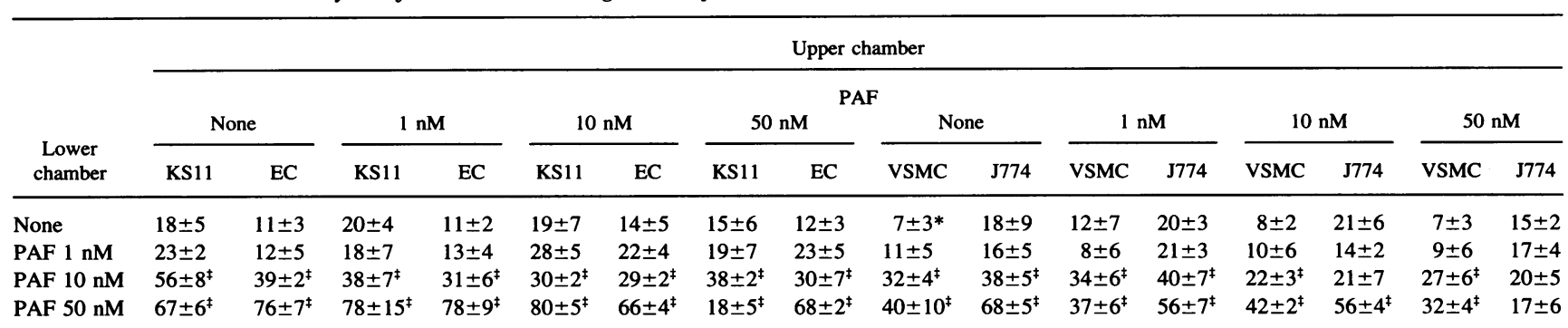

Checkerboard analysis was performed by the Boyden chamber technique as described in Methods by adding PAF in the upper and/or lower compartments of the chamber. Cells migrated after $6 \mathrm{~h}$ of incubation to the lower surface of the filter were counted after coding samples. $*$ The numbers are the mean \pm SD of four fields $(\times 100)$ counted, in a representative experiment out of three. ${ }^{\ddagger} P<0.005$ versus medium control. 
Table III. Effect of KS-CM Medium and of PAF Extracted by KS-CM (KS-PAF) on KS Cell, EC, and J774 Cell Motility

\begin{tabular}{lcccc}
\hline & \multicolumn{4}{c}{ Number of migrated cells } \\
\cline { 2 - 5 } & KS3 & KS8 & EC & J774 \\
\hline Control & $28 \pm 6^{*}$ & $16 \pm 4$ & $20 \pm 8$ & $31 \pm 21$ \\
KS-CM & $160 \pm 13$ & $128 \pm 21$ & $140 \pm 34$ & $88 \pm 10$ \\
KS-CM + WEB 2170 $(10 \mu \mathrm{M})$ & $67 \pm 12$ & $88 \pm 31$ & $50 \pm 21$ & $56 \pm 11$ \\
KS-CM + WEB 2170 $(50 \mu \mathrm{M})$ & $57 \pm 9$ & $52 \pm 14$ & $23 \pm 13$ & $25 \pm 8$ \\
KS-PAF $(10 \mathrm{nM})^{\ddagger}$ & $95 \pm 12$ & $71 \pm 7$ & $47 \pm 11$ & $76 \pm 5$ \\
KS-PAF $(10 \mathrm{nM})+$ WEB & & & & \\
$2170(10 \mu \mathrm{M})$ & $31 \pm 6$ & $12 \pm 9$ & $15 \pm 4$ & $30 \pm 11$ \\
& & & & \\
\hline
\end{tabular}

Migration assay was performed by Boyden's chamber technique as described in Methods and detailed in Table $\mathrm{I}$. * Mean \pm SD of migrated cells counted per microscopic field $(\times 100)$ for triplicate determinations of one experiment out of five. ${ }^{\ddagger}$ KS-PAF was extracted by KS-CM of KS3 cells.

KS cells into Matrigel, the vascularization and the recruitment of macrophages were significantly inhibited (Fig. 3, Fig. 4, $B$ and $D$, and Tables V and VI). The systemic treatment of animals with WEB 2170 induced similar results (Fig. 4 B, Table VI).

To demonstrate the presence in the Matrigel plug of cells bearing PAF-R which can be the putative targets of WEB 2170, sections of the gel were stained with anti-PAF-R antibody. Fig. 6 shows that PAF-R was expressed on the surface of EC lining the lumen of vessels and on leukocytes confined within the vessels.

To confirm that PAF was involved in angiogenesis induced by KS-CM, we studied the effect of synthetic PAF. The injection in mice of Matrigel containing 10 pmol of synthetic PAF was followed by a relevant angiogenic response, which was completely abolished by WEB 2170 (Fig. 4 C). The angiogenic effect of bFGF, however, was not blocked by WEB 2170 (Table VI). Furthermore, PAF extracted and purified from the plasma of a patient with $\mathrm{KS}$ induced an angiogenic response which was blocked by WEB 2170 (Figs. $3 C$ and $4 F$ ).

Role of PAF in initiating the production of chemokines and growth factors during angiogenesis induced by KS-CM. In a

Table IV. Effect of C-PAF on the Proliferation of KS3, EC, and VSMC

\begin{tabular}{lccc}
\hline & \multicolumn{3}{c}{ Cell number $\left(1 \times 10^{3}\right)$} \\
\cline { 2 - 4 } & KS3* & EC & VSMC \\
\hline Control & $2.1 \pm 0.3^{\ddagger}$ & $2.8 \pm 0.4$ & $3.1 \pm 0.9$ \\
Oncostatin M $(50 \mathrm{ng} / \mathrm{ml})$ & $5.3 \pm 1.0$ & Not tested & Not tested \\
FGF $(10 \mathrm{ng} / \mathrm{ml})$ & Not tested & $7.2 \pm 1.3$ & Not tested \\
PDGF $(25 \mathrm{ng} / \mathrm{ml})$ & Not tested & Not tested & $7.9 \pm 0.7$ \\
C-PAF $10 \mathrm{nM}$ & $2.0 \pm 0.4$ & $2.7 \pm 0.3$ & $2.9 \pm 1.3$ \\
C-PAF $100 \mathrm{nM}$ & $2.2 \pm 0.2$ & $2.1 \pm 1.2$ & $3.0 \pm 0.7$ \\
\hline
\end{tabular}

Low density cultures of KS3, EC, and VSMC $\left(1.5 \times 10^{3}\right.$ per $0.32 \mathrm{~cm}^{2}$ well) were incubated in the specific growth medium supplemented with 2.5\% FCS and stimulated every $2 \mathrm{~d}$. Cells were counted after $8 \mathrm{~d}$. * Similar results have been obtained also with KS3 and KS8 cells. ${ }^{\ddagger}$ The data shown are the means of six determinations $\pm S D$ in a representative experiment out of two.

\section{Control}

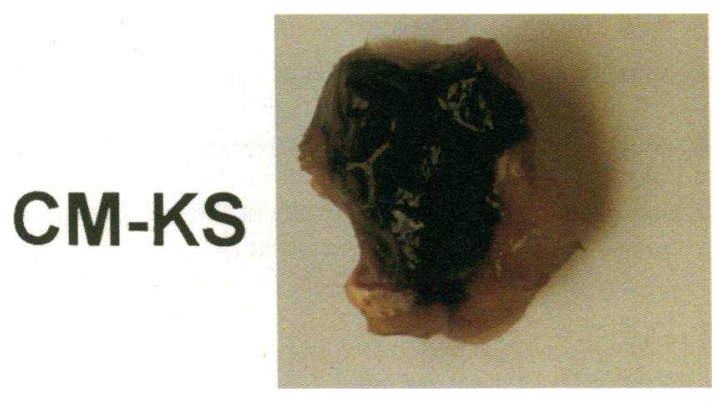

\section{CM-KS+ WEB2170}

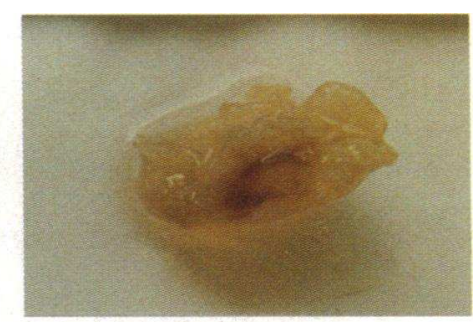

\section{(R)PAF}

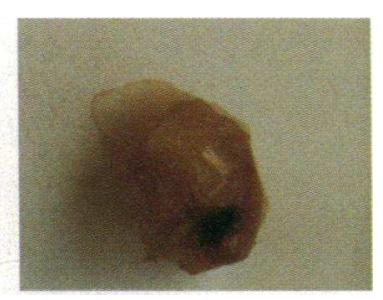

Figure 3. Angiogenesis induced in mice by KS-CM, PAF, and effect of WEB 2170. Matrigel containing heparin $(64 \mathrm{U} / \mathrm{ml})$ was mixed with $20 \mu 1$ of concentrated KS-CM obtained by KS 4 cells, 10 pmol (R)PAF, or $20 \mu \mathrm{l}$ of medium treated as KS-CM ( Control) and injected subcutaneously in DBA/2 mice treated with vehicle or WEB $2170(10 \mathrm{mg} / \mathrm{kg} /$ die, intraperitoneally). Animals were killed at day 8 . Similar results have been obtained in two animals treated with Matrigel containing CM-KC obtained by KS3 and KS8 cells.

series of experiments, we examined in Matrigel plugs the presence of mRNA for cytokines and growth factors that can be active on yascular cells and macrophages, which represent the more abundant infiltrating cells. RNA extracted on days 2 and 7 was analyzed by RT-PCR using primers for MIP-2, KC, JE, PIGF, HGF, VEGF, aFGF, bFGF, FGF-3, K-FGF, FGF-5, FGF- 

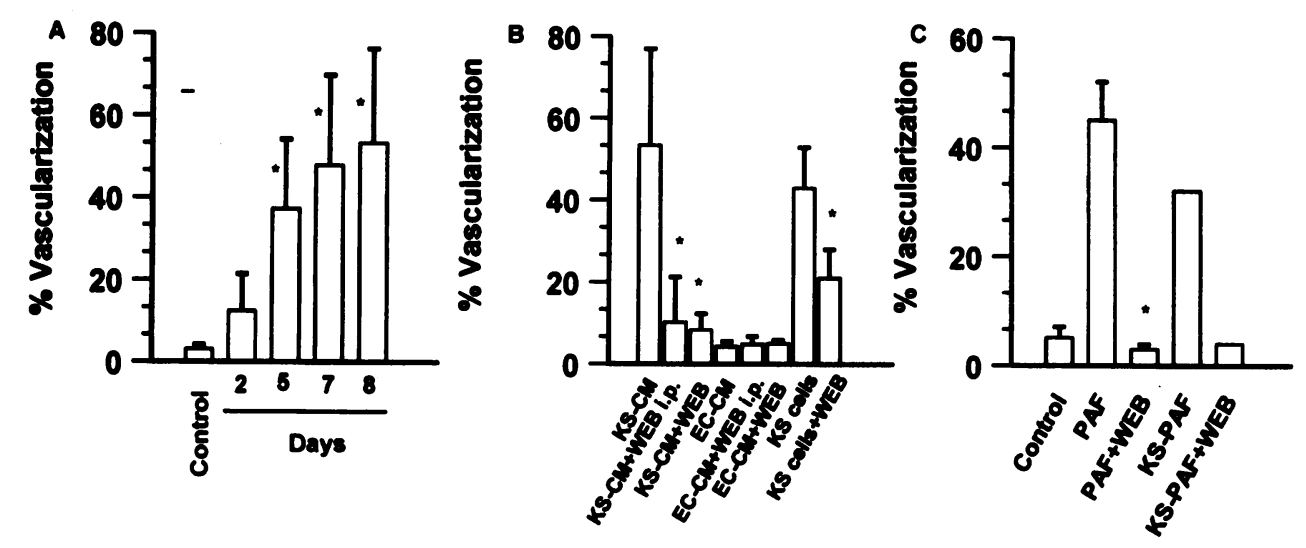

Figure 4. Quantitation of angiogenesis induced by KS-CM, ECCM, AIDS-IST-KS4 cells, and PAF and effect of WEB 2170. Matrigel containing heparin (64 $\mathrm{U} / \mathrm{ml}$ ) was mixed with $20 \mu \mathrm{l}$ of concentrated KS-CM obtained by KS4 cells, EC-CM, $20 \mu$ l of medium treated as KS-CM (Control), or $8 \times 10^{5}$ cells and injected subcutaneously in DBA/2 mice. Quantitation of neovascularization was performed on hematoxylin and eosin-stained histologic section and results were expressed as percentage $\pm S D$ of the vessel area to the total Matrigel area. $(A)$ Time dependence of the effect of KS-CM. (B) Effect of WEB 2170 administered by intraperitoneal injection (WEB i.p. $)(10 \mathrm{mg} / \mathrm{kg} / \mathrm{die})$ or into Matrigel (WEB) $(0.5 \mathrm{mg} / \mathrm{ml})$ on angiogenesis induced by KS-CM, EC-CM, or AIDS-IST-KS cells. The animals were killed after $7 \mathrm{~d}$. $(C)$ Effect of (R)PAF (10 pmol), PAF extracted by plasma of a patient affected by classical KS (KS-PAF), and WEB 2170 added to Matrigel. 8-12 animals were used for each group and the data are mean \pm SD. The experiment in $B$ with AIDS-IST-KS4 cells has been done in two animals and the data are mean \pm SD of different, nonseriated sections (at least four) of the samples. $* P<0.05$ or lower by Wilcoxon rank sum test. Similar results have been obtained in three animals treated with Matrigel containing CM-KC obtained by KS3 and KS8 cells.
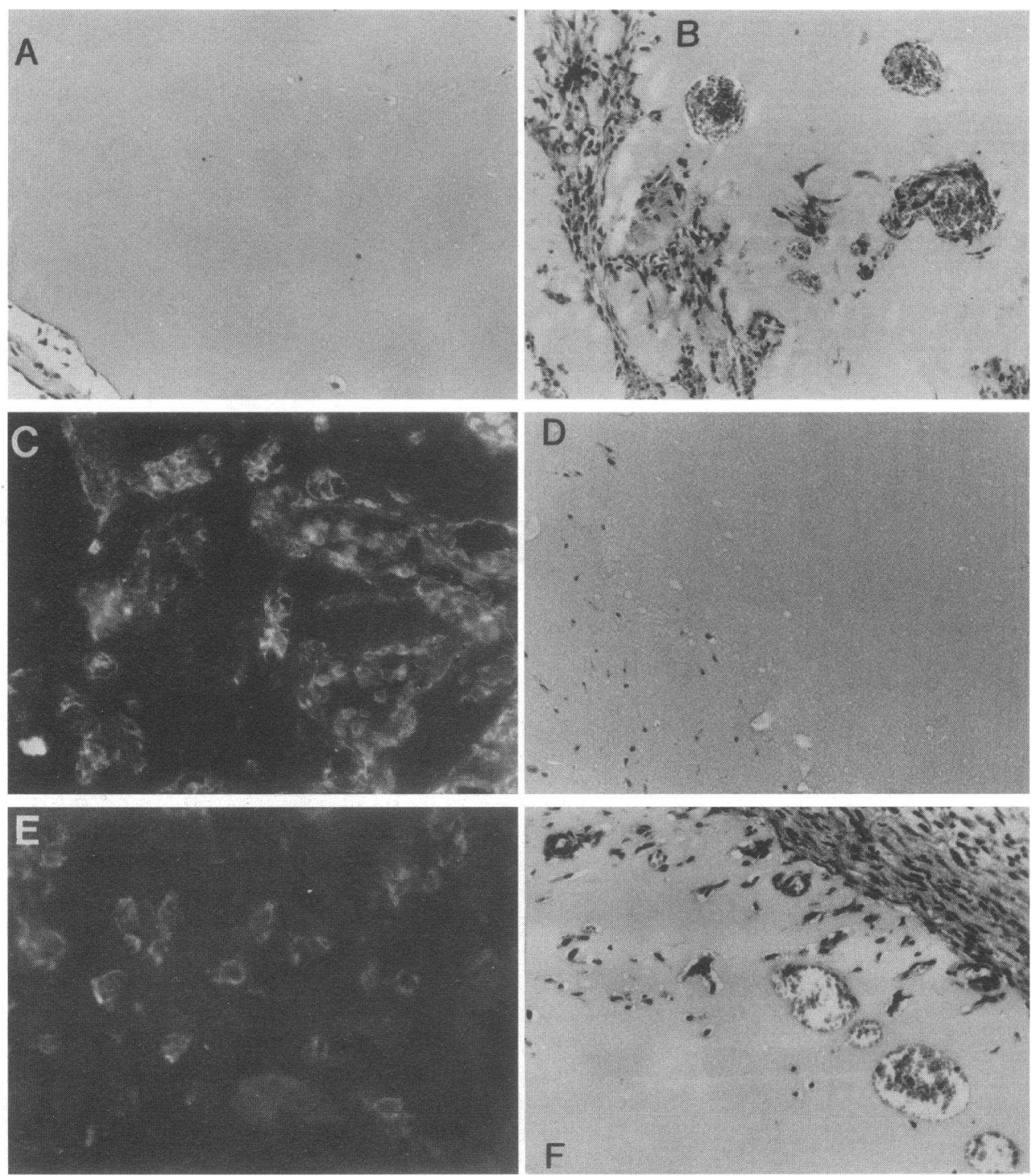

Figure 5. Histological analysis of Matrigel plugs with hematoxylin and eosin staining $(A, B, D$, and $F)$ or with immunofluorescence $(C$ and $E$ ) from mice treated as in the legend to Fig. 4. $(A)$ Control. $(B)$ KS-CM. Canalized vessels and microaneurismatic structures containing erythrocytes are evident. $(C)$ EC stained by indirect immunofluorescence for von Willebrand factor. Penetration of cord of EC and EC lining the lumen of a large vessel are evident. The secondary fluoresceinated goat antirabbit antibody used alone did not stain any cells in Matrigel plug. (D) Inhibitory effect of WEB 2170 added to Matrigel on the effect of KS-CM. (E) Presence of Mac-1-positive cells in Matrigel supplemented with KS-CM stained by direct fluorescence using a mAb anti-Mac-1. $(F)$ Angiogenic effect of PAF extracted from the plasma of a patient affected by classical KS. $A, D$, and $F, \times 100 ; B, C$, and $E, \times 200$. Animals were killed at day 5 ( $A-D$ and $F)$ or $7(E)$. 
Table V. Lymphomononuclear Cell Infiltrate in Angiogenesis Induced by KS-CM

\begin{tabular}{|c|c|c|c|c|c|c|}
\hline \multirow[b]{3}{*}{ Antibody } & \multicolumn{6}{|c|}{ Percent positive cells } \\
\hline & \multicolumn{2}{|c|}{ Day 2} & \multicolumn{2}{|c|}{ Day 4} & \multicolumn{2}{|c|}{ Day 7} \\
\hline & KS-CM & KS-CM + WEB 2170 & KS-CM & KS-CM + WEB 2170 & KS-CM & KS-CM + WEB 2170 \\
\hline Anti-Mac-1 & $10 \pm 5^{*}$ & $2 \pm 2$ & $46 \pm 12$ & $3 \pm 1$ & $53 \pm 16$ & $4 \pm 2$ \\
\hline Anti-L3 & 0 & 0 & $7 \pm 3$ & 0 & $10 \pm 7$ & 0 \\
\hline Anti-Ly2 & 0 & 0 & $3 \pm 2$ & 0 & $4 \pm 3$ & 0 \\
\hline
\end{tabular}

Matrigel $(0.5 \mathrm{ml})$ containing $64 \mathrm{U} / \mathrm{ml}$ heparin was mixed with $20 \mu \mathrm{l}$ of concentrated KS-CM obtained by KS3 cells with or without WEB 2170 $(0.5 \mathrm{mg} / \mathrm{ml})$ and injected into the abdominal subcutaneous tissue of mice along the peritoneal midline. Mice were killed at the indicated time. The Matrigel plugs were processed for immunofluorescence performed with the indicated fluoresceinated $\mathrm{mAb} .{ }^{*}$ The numbers are mean \pm SD of positive cells present in four microscopic fields $(\times 100)$.

6, and FGF-7. As shown in Fig. 7, the transcripts for KC, MIP2, PIGF, aFGF, and HGF were already present on day 2, whereas mRNA for VEGF-1 and bFGF were detectable only on day 7. mRNA of JE, FGF-3, K-FGF, FGF-5, FGF-6, and FGF-7 was always undetectable in Matrigel plugs (Fig. 7 and not shown). The amount of RNA in control plugs was at least 50-fold lower than that detected in Matrigel plugs containing KS-CM. However, the transcripts of the studied chemokines and growth factors were absent in the pooled RNA extracted from five different control plugs (not shown). It was important to establish whether cytokine and growth factor gene expression induced by KS-CM in Matrigel plug was accompanied by production of these molecules. As shown in Fig. 6, histological sections of Matrigel plugs were stained by immunofluorescence

Table VI. Effect of WEB 2170 on KS-CM-induced Angiogenesis

\begin{tabular}{|c|c|}
\hline Treatment & Percent vascularized area \\
\hline None & $6 \pm 3$ \\
\hline $\mathrm{KS}-\mathrm{CM}$ & $53 \pm 14$ \\
\hline KS-CM + WEB $2170(50 \mu \mathrm{g} / \mathrm{ml}$ Matrigel $)$ & $50 \pm 12$ \\
\hline KS-CM + WEB $2170(100 \mu \mathrm{g} / \mathrm{ml}$ Matrigel $)$ & $30 \pm 19$ \\
\hline KS-CM + WEB $2170(250 \mu \mathrm{g} / \mathrm{ml}$ Matrigel $)$ & $15 \pm 11$ \\
\hline KS-CM + WEB $2170(500 \mu \mathrm{g} / \mathrm{ml}$ Matrigel $)$ & $10 \pm 5$ \\
\hline WEB $2170(500 \mu \mathrm{g} / \mathrm{ml}$ Matrigel $)$ & $11 \pm 7$ \\
\hline KS-CM + WEB 2170 (1 mg/kg/die, i.p.) & $46 \pm 9$ \\
\hline KS-CM + WEB 2170 (3 mg/kg/die, i.p.) & $30 \pm 11$ \\
\hline KS-CM + WEB 2170 (10 mg/kg/die, i.p.) & $11 \pm 10$ \\
\hline WEB 2170 (10 mg/kg/die, i.p.) & $6 \pm 3$ \\
\hline bFGF (20 ng/ml Matrigel) & $88 \pm 12$ \\
\hline bFGF + WEB $2170(500 \mu \mathrm{g} / \mathrm{ml}$ Matrigel $)$ & $81 \pm 15$ \\
\hline bFGF + WEB $2170(10 \mathrm{mg} / \mathrm{kg} / \mathrm{die}$, i.p. $)$ & $90 \pm 21$ \\
\hline
\end{tabular}

Matrigel $(0.5 \mathrm{ml})$ containing $64 \mathrm{U} / \mathrm{ml}$ heparin was mixed with $20 \mu \mathrm{l}$ of concentrated KS-CM obtained by KS3 cells or with bFGF and injected into the abdominal subcutaneous tissue of mice along the peritoneal midline. WEB 2170 was added into Matrigel or administered by intraperitoneal injection. Mice were killed after $8 \mathrm{~d}$. Quantitation of neovascularization was performed on hematoxylin and eosin-stained histologic section and results were expressed as percentage \pm SD of the vessel area to the total Matrigel area. Four animals were used for each group and the data are mean \pm SD. $500 \mu \mathrm{g}$ of WEB 2170 for milliliters corresponded to $1.06 \mu \mathrm{mol} / \mathrm{ml}$ and $10 \mathrm{mg} / \mathrm{kg}$ to $21.3 \mu \mathrm{mol} / \mathrm{kg}$. with anti-VEGF and anti-bFGF antibodies. At day 7, infiltrating cells expressed both angiogenic factors (Fig. 6, $C$ and $E$ ), whereas EC and cells within the vessels were negative (not shown). To better define the role of one of these angiogenic molecules present in the angiogenesis process triggered by KS$\mathrm{CM}$, we examined the expression of VEGF receptor encoded by the gene $f l k-1$ (76-78). Fig. $6 D$ shows that VEGF receptor was distributed in a pattern consistent with expression on the surface of EC lining large and small vessels.

Treatment of mice with WEB 2170 abolished the appearance of the transcripts studied (Fig. 7) in the Matrigel containing KS-CM as well as the production of bFGF (Fig. $6 F$ ).

\section{Discussion}

KS is a highly vascularized neoplasm, the nature of which is still an enigma $(8,13)$. The ontogenetic origin of $\mathrm{KS}$ has not been unequivocally defined $(8-12)$. Spindle cells represent the core of the lesion and consist of at least two populations, one expressing fibro-endothelial markers and the other a phenotype typical of monocytoid cells (11). Furthermore, they also express smooth muscle $\alpha$-actin $(58,59)$. The existence of a mesenchymal progenitor of vascular cells (58), which could be stimulated to grow as a consequence of cytokine imbalance, has been postulated.

Some experimental observations indicate that angiogenesis is a relevant process leading to progression of the lesion. KS cells produce factors which cause an angiogenic response (33, $34)$. Furthermore, angiogenic factors and a receptor for FGF are highly expressed in vivo in $\mathrm{KS}(26,35-38)$. Sulfated polysaccharide peptidoglycan, which inhibits the in vitro growth of $\mathrm{EC}$ and $\mathrm{KS}$ cells, also reduces in vivo the angiogenesis and the proliferative lesions induced by KS cells (7); IFN- $\alpha$, a cytokine used in the management of infantile hemangiomas, is also used in the treatment of KS (79).

The data reported herein suggest that PAF is produced by KS cells and that it has autocrine effects on KS cells and paracrine effects on EC and VSMC. This conclusion is based on the following observations: $(a)$ unstimulated KS cells contain low amounts of PAF which accumulate in conditioned medium after long-term incubation; $(b)$ synthesis of PAF was increased by $\mathrm{Thr}$ and by inflammatory cytokines, which also enhanced the release of the mediator; $(c)$ the amount of PAF produced by $\mathrm{KS}$ cells is sufficient to activate the PAF-R and elicit a 

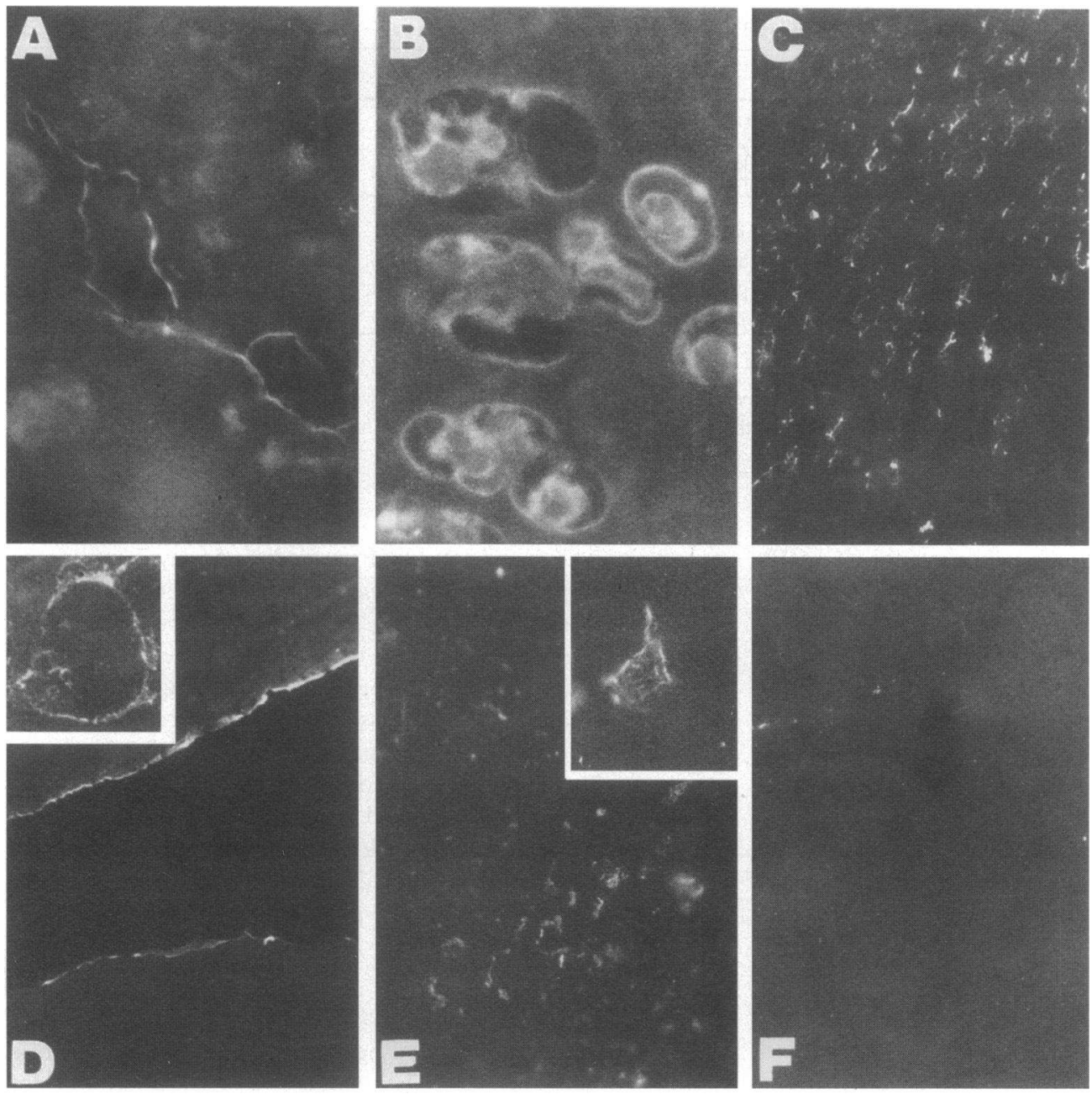

Figure 6. Immunohistochemical detection of PAF-R ( $A$ and $B)$, $\operatorname{VEGF}(C), f l k-1(D)$, and bFGF ( $E$ and $F$ ) in Matrigel plug containing KS-CM. Matrigel containing heparin $(64 \mathrm{U} / \mathrm{ml})$ was mixed with $20 \mu \mathrm{l} \mathrm{KS-CM}$ and injected subcutaneously in $\mathrm{DBA} / 2$ mice. ( $A$ ) EC lining the lumen of vessels infiltrating the Matrigel stained by indirect fluorescence for PAF-R $(\times 160)$. (B) Small vessels infiltrating Matrigel containing few circulating cells positive for PAF-R ( $\times 400)$. ( C ) Matrigel infiltrating cells stained by indirect fluorescence for VEGF $(\times 160)$. (D) EC lining the lumen of a large $(\times 160)$ and a small vessel (inset, $\times 600$ ) stained by indirect fluorescence for $f l k-1$. ( $E)$ Expression of bFGF by infiltrating cells $(\times 160$; inset, $\times 600)$ stained by indirect fluorescence for bFGF. $(F)$ Effect of WEB 2170 on KS$\mathrm{CM}$-induced expression of bFGF. The treatment of mice with WEB 2170 (10 mg/kg/ die) abolished completely the expression of bFGF. Animals were killed on day 7 . The secondary fluoresceinated goat anti-rabbit antibody used alone did not stain any cells in Matrigel plug. biological response $(41,42)$; (d) KS cells have a specific, biologically active PAF-R with an apparent $K_{\mathrm{d}}$ value similar to that demonstrated in various other cell types (revised in references 41 and 42 ); and (e) PAF produced by KS cells induces receptor-dependent motility of $\mathrm{KS}, \mathrm{EC}$, and VSMC since a PAF-R antagonist WEB 2170 blocks its effect.

As reported for EC (44-48), KS cells are capable either of a rapid or delayed synthesis of PAF depending on the nature of the stimuli. Thr caused a rapid synthesis of this mediator, whereas IL-1 and TNF induced a delayed synthesis. This suggests an ontogenic relationship between KS and EC differentiation pathways. The levels of cytokines that induced PAF synthesis were shown to be increased in HIV-1-infected patients with KS (2). In addition, clinical studies using TNF for the treatment of $\mathrm{KS}$ revealed that this cytokine exacerbates the disease (80).

We also demonstrated that PAF induced directed (chemotaxis) and random (chemokinesis) migration of KS cells, through interaction with its specific receptor expressed at their surface, since the PAF-R antagonist WEB 2170 showed an inhibitory effect. Similar migratory responses were observed for EC and VSMC. These data are consistent with the morphological alterations and the redistribution of cytoskeletal proteins caused by PAF in EC $(53,55)$.

A crucial step in the sequence of events that leads to the angiogenic response is the invasion of the perivascular matrix by sprouting EC. The process includes firstly motility and production of lytic enzymes enabling extracellular matrix penetration and then proliferation of EC. Many angiogenic factors stimulate the migration of $\mathrm{EC}$ in vitro, but not their proliferation (81). It was reported that TNF, which inhibits in vitro EC proliferation, has angiogenic properties in vivo (82). We recently suggested that PAF is a secondary mediator for TNF- $\alpha-$ induced angiogenesis (65). Herein, we brought evidence that PAF containing KS-CM was able to stimulate EC migration and to promote angiogenesis in the mouse. Moreover PAF extracted and purified from plasmas of two classical KS was found to be angiogenic. The angiogenic and migratory effects of KS$\mathrm{CM}$ were inhibited in a dose-dependent manner by the specific PAF-R antagonist, WEB 2170 (66). The minimal concentration of WEB 2170 active in vivo by intraperitoneal administration ( $3 \mathrm{mg} / \mathrm{kg} / \mathrm{die})$ or when administered in a single dose inside the Matrigel $(100 \mu \mathrm{g} / \mathrm{ml})$ was $\sim 50$-fold higher than that effective in vitro on cell migration (Table I and Fig. 2), but similar to that active in other animal experimental models $(66,83$, 84). WEB 2170 belongs to the family of hetrazepinoic PAF-R antagonists (66) derived from the hypnotic drug brotizolam. However, the affinity of WEB 2170 for the central benzodiazepine receptor is several hundredfold less than that of brotizolam, whereas the calculated $K_{\mathrm{d}}$ for PAF-R is similar whether PAF or WEB 2170 is used as ligand $(66,83)$. The binding of WEB 


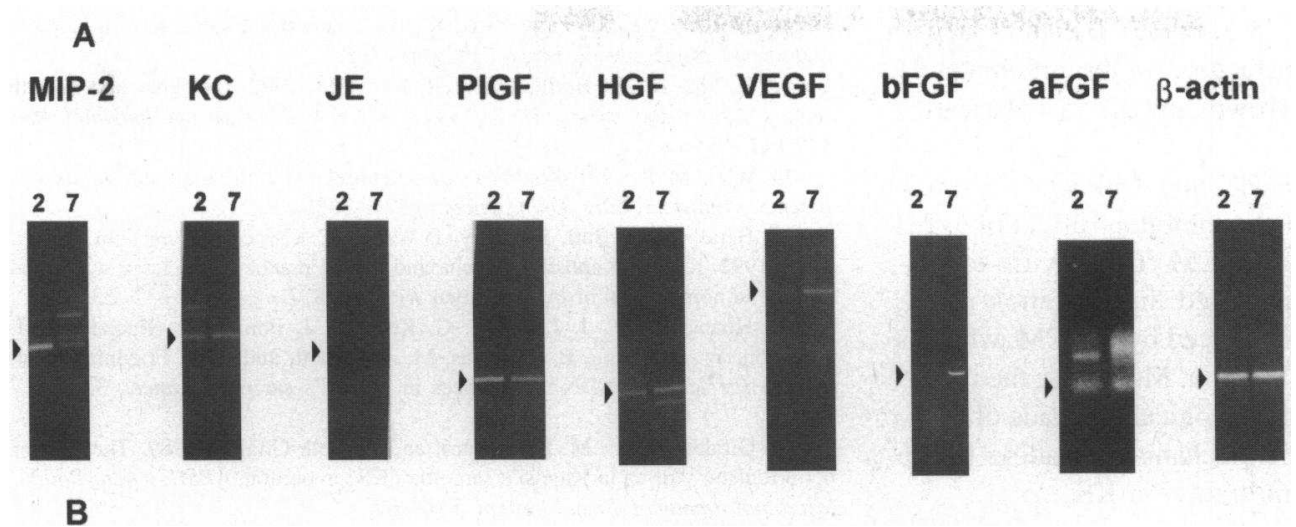

Figure 7. Expression of chemokine and growth factor genes in Matrigel plugs. Matrigel containing heparin $(64 \mathrm{U} / \mathrm{ml})$ was mixed with $20 \mu \mathrm{l} \mathrm{KS}-\mathrm{CM}$ and injected subcutaneously in DBA/2 mice treated with vehicle $(A)$ or WEB $2170(10 \mathrm{mg} / \mathrm{kg} / \mathrm{die}$, intraperitoneally) $(B)$. Total RNA extracted from Matrigel plugs at days 2 (lane 2) and 7 (lane 7) was reverse transcribed and amplified by PCR as described in Methods, using specific primers for the indicated chemokines and growth factors. Products of amplification were analyzed on a $1.8 \%$ agarose gel and visualized by ethidium bromide fluorescence. The size of

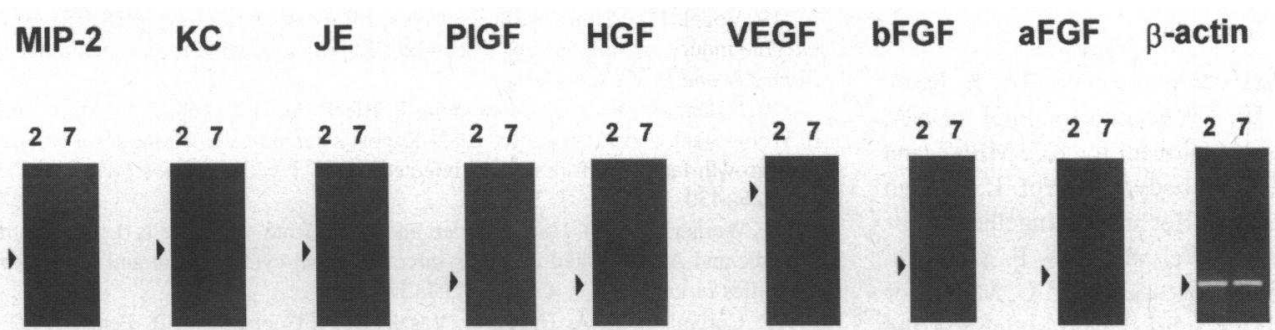
the amplified bands were as follows (bp): MIP-2, 210; KC, 206; JE, 270; PIGF, 268; HGF, 269; VEGF, 580; bFGF, 234; aFGF, 235 ; $\beta$-actin, 245 . They correspond to the selected region of the cDNAs. The figure is representative of the analysis of RNA extracted from one Matrigel plug out of six done with similar results. RNA extracted from the controls (range from 0 to $1 \mu \mathrm{g}, n=5$ ) was pooled and submitted to RT-PCR with negative results.

2170 to the PAF-R is stereospecific, the (-) optical enantiomer being more potent in inhibiting PAF-induced platelet aggregation (84). Furthermore, at the concentrations used in vivo and in vitro in this study, WEB 2170 did not block the action of other soluble mediators (66) or the angiogenic effect of bFGF (Table VI).

The angiogenic response to KS-CM is also characterized by the expression of genes for chemokines such as MIP-2 (71) and $\mathrm{KC}(64)$ and angiogenic factors, including VEGF-1 (68, $77,78), a F G F$ and bFGF $(73,81), \operatorname{HGF}(60), \operatorname{PIGF}(84,85)$, and $\mathrm{KC}$, the murine counterpart of IL-8 (86). The expression of other members of FGF family, (e.g., FGF-3/int-2, FGF-4, FGF-5, and FGF-6) which can be expressed in KS lesions other than aFGF and bFGF (35-38), was not induced by KS-CM. MIP-2, KC, PIGF, aFGF, and HGF transcripts were already present on day 2, whereas mRNA of VEGF and bFGF appeared on day 7 , suggesting that $\mathrm{KS}-\mathrm{CM}$ triggers sequential events leading to a progressively amplified angiogenic process. In this respect, we observed that infiltrating cells, but not EC, were VEGF immunopositive. In addition, the VEGF receptor encoded by $f l k-1$ gene, which is specific for endothelium $(77,78)$, was present on EC lining the new vessels. This result suggests that, in this model, VEGF and its receptor are implicated in the process of amplification. We can speculate that bFGF and aFGF have a similar role, since we observed that infiltrating cells produced bFGF. The KS-CM cellular targets which produce chemokines and angiogenic growth factor(s) are unknown. However, we found that KS-CM induced a prominent infiltration of macrophages, which can produce VEGF (87) and bFGF (88). With regard to chemokines, both EC and macrophages can be producers (revised in reference 89 ). The PAF-R antagonist WEB 2170 prevented the recruitment of macrophages and the expression of genes for chemokines and growth factors as well as the production of bFGF within Matrigel containing KSCM. Further, WEB 2170 blocked the PAF-induced in vitro migration of a macrophage cell line. Therefore, these results suggest that PAF is chronologically one of the first mediators which triggers the angiogenesis process caused by KS-CM. Our results do not elucidate how PAF upregulates the expression of growth factors and chemokines in angiogenesis. However, it has been reported that PAF modulates cytokine $(90,91)$ and enzyme (92) expression by regulating transcription (93).

PAF produced by KS cells and present in KS-CM may be expected to induce angiogenesis in two ways: directly, by serving as an EC motogen and inductor of functions related to angiogenesis, and indirectly, by attracting macrophages and thereby promoting the production of angiogenic factors (89).

This model of angiogenesis induced by KS-CM is supported by some observations done on KS. It has been demonstrated that FGFs (35-38), PDGF (26), HGF (40), and VEGF (39) participate in angiogenesis associated with KS, since their transcripts have been detected in vivo in the lesion or in vitro in KS cells $(26,35-38)$. Further, KS cells express appreciable amounts of the chemokine IL-8 and monocyte chemotactic protein-1, which are augmented by IL-1 or TNF (94). Monocyte chemotactic protein-1 expression is also present in KS lesions (94) and can explain the presence of the prominent leukocyte infiltration in $\mathrm{KS}$ lesions $(8,33)$.

It is conceivable that the development of $\mathrm{KS}$ is due to an imbalance in the network of soluble mediators acting on progressive steps. Oncostatin M, IL-6, and other molecules produced by HIV-1-infected lymphomononuclear cells or Tat protein can induce a hypothetical precursor to differentiate into spindle cells $(24,25,27-30)$ and sustain the growth of these "transformed cells." At the same time, mediators released by spindle cells, including PAF, may implement the angiogenic 
response and the recruitment of leukocytes. The final step is the release of angiogenic growth factors by the inflammatory infiltrate which amplify both the growth and the vascularization of KS lesions.

In the model here described, EC and leukocytes express PAF-R and can be the targets for the inhibitory effect of WEB 2170 on angiogenesis induced by KS-CM. The in vitro experiments indicate that WEB 2170 inhibited the migration of EC and a murine macrophage cell line induced by KS-CM, whereas it was less effective on KS cell migration. Moreover, the results of this study suggest that the pharmacological blockade of PAF$R$ can be useful in the control of mechanisms leading to the angiogenesis and the leukocyte infiltration in KS.

\section{Acknowledgments}

We thank Dr. R. Ye for providing PAF receptor cDNA, Dr. E. Risau and Dr. G. Breier for VEGF cDNA, Dr. M. Persico for PIGF cDNA, Dr. G. Gaudino for HGF cDNA, Dr. A. Mantovani for KC, MIP-2, and JE cDNAs, Dr. M. Presta for anti-bFGF antibody, and Prof. L. Silengo for FGF cDNAs. Immunex, Genentech, and Boehringer-Ingelheim provided the cytokines used and WEB 2170. We thank Drs. F. Malavasi, A. Mantovani, and P. Gullino for helpful suggestions, Dr. U. Mazza for the blood of KS patients, and Dr. D. Maglione who suggested the oligonucleotides of murine PIGH used in RT-PCR on the basis of the unpublished sequence.

This work was supported by C. N. R. (Targets Projects: Applicazioni Cliniche della Ricerca Oncologica, Ingegneria Genetica and Prevention and Control of Disease Factors FATMA, subproject "Causes of infective diseases," CT 9300607.PF41), by Istituto Superiore della Sanità (VII Progetto AIDS), by Associazione Italiana per la Ricerca sul Cancro, by Telethon, and by the Medical Research Council of Cancer (G. Montrucchio and M. Rola-Pleszczynski). M. Arese is a fellow of Fondazione Italiana per la Ricerca sul Cancro.

\section{References}

1. Havercos, H. W., D. P. Drotman, and M. Morgan. 1985. Prevalence of Kaposi's sarcoma among patients with AIDS. N. Engl. J. Med. 312:1518-1523.

2. Safai, B., K. G. Johnson, P. L. Myskowski, B. Koziner, S. Y. Yang, S. Cunningan-Rundles, J. H. Godbold, and B. Dupont. 1985. The natural history of Kaposi's sarcoma in the acquired immunodeficiency syndrome. Ann. Intern. Med. 103:744-750.

3. CDC Task Force on KS and Opportunistic Infections. 1982. N. Engl. J. Med. 103:248-252.

4. Gill, P., M. Rarick, M. Bernstein-Singer, M. Harb, B. M. Espina, V. Shaw, and A. Levine. 1990. Treatment of advanced Kaposi's sarcoma using a combination of bleomycin and vincristine. Am. J. Clin. Oncol. 13:315-319.

5. Tappero, J. W., M. A. Conant, S. F. Wolfe, and T. G. Berger. 1993. Kaposi's sarcoma. Epidemiology, pathogenesis, histology, clinical spectrum staging criteria and therapy. J. Am. Acad. Dermatol. 28:371-395.

6. Khan, J. O., D. W. Northfelt, and S. A. Miles. 1992. AIDS associated Kaposi's sarcoma. AIDS Clin. Rev. 4:261-280.

7. Nakamura, S., S. Sakurada, S. Z. Salahuddin, Y. Osada, N. G. Tanaka, N. Sakamoto, M. Sekiguchi, and R. C. Gallo. 1992. Inhibition of development of Kaposi's sarcoma-related lesions by a bacterial cell wall complex. Science (Wash. DC). 255:1437-1440.

8. Armes, J. 1989. A review of Kaposi's sarcoma. Adv. Canc. Res. 53:73-

9. Harrison, A. C., and L. B. Kahn. 1978. Myogenic cells in Kaposi's sarcoma: an ultrastructural study. J. Pathol. 124:157-160.

10. McNutt, N. S., V. Fletcher, and M. A. Canent. 1983. Early lesions of Kaposi's sarcoma in homosexual men. An ultrastructural comparison with other vascular proliferation in skin. Am. J. Pathol. 111:62-77.

11. Kaaya, E. E., C. Parravicini, B. Sundelin, E. Mgaya, J. Kitinya, L. Lema, J. Luande, and P. Biberfeld. 1992. Spindle cell ploidy and proliferation in endemic and epidemic African Kaposi's sarcoma. Eur. J. Cancer. 28A:1890-1894.

12. Rutgers, J. L., R. Wieczorek, F. Bonett, K. L. Kaplan, D. N. Posnett, A. E Friedman-Kien, and D. M. Knowles. 1986. The expression of endothelial cells surface antigens by AIDS-associated Kaposi's sarcoma. Evidence for a vascular endothelial origin. Am. J. Pathol. 122:493-498.

13. Ensoli, B., G. Barillari, and R. C. Gallo. 1992. Cytokine and growth factors in the pathogenesis of AIDS-associated Kaposi's sarcoma. Immunol. Rev. 127:147-155.

14. Wick, M. R. 1991. Kaposi's sarcoma unrelated to the acquired immunodeficiency syndrome. Curr. Opin. Oncol. 3:377-383.

15. Beral, V., D. Bull, S. Darby, I. Weller, C. Carne, M. Beecham, and H. Jaffe. 1992. Risk of Kaposi's sarcoma and sexual practice associated with fecal contact in homosexual or bisexual men with AIDS. Lancet. 339:632-635.

16. Huang, Y. Q., J. J. Li, M. G. Rush, B. J. Poiesz, A. Nicolaides, M. Jacobson, W. G. Zhang, E. Coutavas, M. A. Abbott, and A. E. Friedman-Kien. 1992. HPV-16-related DNA sequences in Kaposi's sarcoma. Lancet. 339:515518.

17. Giraldo, G., F. M. Buonaguro, and E. Beth-Giraldo. 1989. The role of opportunistic viruses in Kaposi's sarcoma (KS) evolution. APMIS (Acta Pathol. Microbiol. Immunol. Scand.) Suppl. 8:62-69.

18. Taylor, J. F., P. G. Smith, D. Bull, and M. C. Pike. 1972. Kaposi's sarcoma in Uganda: geographic and ethnic distribution. Br. J. Cancer. 26:483-497.

19. Vogel, J., S. Hinrichs, R. Reynolds, J. Luviw, and G. Jay. 1988. The HIV tat gene induces dermal lesions resembling Kaposi's sarcoma in transgenic mice. Nature (Lond.). 335:606-611.

20. Nakamura, S., S. Z. Salahuddin, P. Biberfeld, B. Ensoli, P. D. Markham, F. Wong-Staal, and R. V. Gallo. 1988. Kaposi's sarcoma cells: long-term culture with growth factor from retrovirus-infected $\mathrm{CD}^{+} \mathrm{T}$ cells. Science (Wash. DC). 242:426-430.

21. Werner, S., P. H. Hofachneider, and W. K. Roth. 1989. Cells derived from sporadic and AIDS-related Kaposi's sarcoma reveal cytochemical and molecular properties in vitro. Int. J. Cancer. 43:1137-1144.

22. Corbeil, J., L. A. Evans, E. Vasak, D. A. Cooper, and R. Penny. 1991. Culture and properties of cells derived from Kaposi's sarcoma. J. Immunol. 146:2972-2976.

23. Albini, A., L. Repetto, S. Carlone, R. Benelli, M. Soria, L. Monaco, R. Gendelman, P. Defilippi, F. Bussolino, and C. Parravicini. 1992. Characterisation of Kaposi's sarcoma-derived cell cultures from an epidemic and classic case. Int. J. Oncol. 1:723-730.

24. Ensoli, B., S. Nakamura, S. Z. Salahuddin, P. Biberfeld, L. Larsson, B. Beaver, F. Wong-Staal, and R. C. Gallo. 1989. AIDS Kaposi's sarcoma derived cells express cytokines with autocrine and paracrine growth effects. Science (Wash. DC). 243:223-226.

25. Miles, S. A., A. Rezai, J. F. Salazar-Gonzales, M. V. Meyden, H. Stevens, D. M. Logan, R. T. Mitsuyasu, T. Taga, T. Hirano, and O. Martinez-Maza. 1990 AIDS-Kaposi's sarcoma derived cells produce and respond to interleukin 6. Proc. Natl. Acad. Sci. USA. 87:4068-4071.

26. Sturzl, M., W. K. Roth, N. H. Brockmeyer, C. Zietz, B. Speiser, and P. H. Hofschneider. 1992. Expression of platelet-derived growth factor and its receptor in AIDS-related Kaposi's sarcoma in vivo suggests paracrine and autocrine mechanisms of tumor maintenance. Proc. Natl. Acad Sci. USA. 89:7046-7050.

27. Nair, B. C., A. L. DeVico, S. Nakamura, T. D. Copeland, Y. Chen, S. Patel, S. O'Neil, S. Oroszlan, R. C. Gallo, and M. G. Sarngadharan. 1992. Identification of a major growth factor for AIDS-Kaposi's sarcoma cells as oncostatin M. Science (Wash. DC). 255:1430-1432.

28. Miles, S. A., O. Martien-Maza, A. Rezai, L. Maypantay, T. Kishimoto, S. Nakamura, S. F. Radka, and P. S. Linsey. 1992. Oncostatin M as a potent mitogen for AIDS-KS derived cells. Science (Wash. DC). 255:1432-1434.

29. Ensoli, B., G. Barillari, S. Z. Salahuddin, R. C. Gallo, and F. Wong-Staal. 1990. Tat protein of HIV-1 stimulates growth of cells derived from KaposiUs sarcoma lesions of AIDS patients. Nature (Lond.). 345:84-86.

30. Barillari, G., L. Buonaguro, V. Fiorelli, J. Hoffman, F. Michaels, R. C. Gallo, and B. Ensoli. 1992. Effects of cytokines from activated immune cells on vascular cells growth and HIV-gene expression. Implications for AIDS-Kaposi's sarcoma pathogenesis. J. Immunol. 149:3727-3734.

31. Albini, A., C. W. Mitchell, E. W. Thompson, R. Seeman, G. R. Martin A. E. Wittek, and G. W. Quinnan. 1988. Invasive activity and chemotactic response to growth factors by Kaposi's sarcoma cells. J. Cell. Biochem. 36:369376.

32. Thompson, E. W., S. Nakamura, T. B. Shima, A. Melchiori, G. R. Martin, S. Z. Salahuddin, R. C. Gallo, and A. Albini. 1991. Supernatants of acquired immunodeficiency syndrome-related Kaposi's sarcoma cells induce endothelial cell chemotaxis and invasiveness. Cancer Res. 51:2670-2676.

33. Salahuddin, S. Z., S. Nakamura, P. Biberfeld, M. H. Kaplan, P. D. Markham, L. Larsson, and R. C. Gallo. 1988. Angiogenic properties of Kaposi's sarcoma-derived cells after long-term culture in vitro. Science (Wash. DC). 242:430-433.

34. Albini, A., G. Fontanini, L. Masiello, C. Tacchetti, and W. G. StetlerStevenso. 1994. Angiogenic potential in vivo by Kaposi's sarcoma cell-free supernatants and HIV-tat product: inhibition of KS-like lesions by TIMP-2. AIDS (Phila.). 8:1237-1244. 
35. Delli Bovi, P., A. M. Curatola, F. G. Kern, A. Greco, M. Ittmann, and C. Basilico. 1987. An oncogene isolated by transfection of Kaposi's sarcoma DNA encodes a growth factor that is member of the FGF family. Cell. 50:729-737.

36. Xerri, L., J. Hassoun, J. Plance, V. Guigou, J. J. Grobb, P. Patricza, D. Sirnabaum, and O. de Lapierre. 1991. Fibroblast growth factor gene expression in AIDS-Kaposi's sarcoma detected by in situ hybridisation. Am. J. Pathol. 38:915.

37. Huang, Y. Q., J. J. Li, D. Moscatelli, C. Basilico, A. Nicolaides, W. G. Zhang, B. J. Poiesz, and A. E. Friedman-Kien. 1993. Expression of Int-2 oncogene in Kaposi's sarcoma lesions. J. Clin. Invest. 91:1191-1197.

38. Li, J. J., Y. Q. Huang, D. Moscatelli, A. Nicolaides, W. C. Zhang, and A. E. Friedman-Kien. 1993. Expression of fibroblast growth factors and their receptors in acquired immunodeficiency syndrome-associated Kaposi's sarcoma tissue and derived cells. Cancer (Phila.). 72:2253-2259.

39. Weindel, K., D. Marme, and H. A. Weich. 1992. AIDS-associated Kaposi's sarcoma cells in culture express vascular endothelial growth factor. Biochem. Biophys. Res. Commun. 183:1167-1174.

40. Naidu, Y. M., M. E. Rosen, R. Zitnick, I. Goldberg, M. Park, M. Naujorak, P. J. Polverini, and B. J. Nickoloff. 1994. Role of scatter factor in the pathogenesis of AIDS-related Kaposi's sarcoma. Proc. Natl. Acad. Sci. USA. 91:5281-5285.

41. Snyder, F. 1987. Platelet-Activating Factor and Related Lipid Mediators Plenum Press, New York. 442 pp.

42. Prescott, S. M., G. A. Zimmerman, and T. M. McIntyre. 1990. Plateletactivating factor. J. Biol. Chem. 268:17381-17384.

43. McManus, L. M., D. S. Woodard, S. I. Deavers, and R. N. Pinckard. 1993. PAF molecular heterogeneity: pathobiological implications. Lab. Invest. 69:639650.

44. Camussi, G., M. Aglietta, F. Malavasi, C. Tetta, F. Sanavio, W. Piacibello and F. Bussolino. 1983. The release of platelet activating factor from human endothelial cells in culture. J. Immunol. 131:2397-2403.

45. Prescott, S. M., G. A. Zimmerman, and T. M. McIntyre. 1984. Human endothelial cells in culture produce platelet-activating factor (1-alkyl-2-acetyl-snglyceryl-3-phosphocholine) when stimulated with thrombin. Proc. Natl. Acad. Sci. USA. 81:3934-3938.

46. Bussolino, F., G. Camussi, and C. Baglioni. 1988. Synthesis and release of platelet activating factor by human vascular endothelial cells treated with tumor necrosis factor and interleukin 1a. J. Biol. Chem. 263:11856-11862.

47. Lacasse, C., and M. Rola-Pleszczynski. 1990. Immune regulation by platelet-activating factor. II. Mediation of suppression by cytokine-stimulated endothelial cells in vitro. J. Leukocyte Biol. 49:245-252.

48. Kuijpers, T. W., B. C. Hakkert, M. H. L. Hart, and D. Roos. 1992. Neutrophil migration across monolayers of cytokine-prestimulated endothelial cells: a role for platelet-activating factor and IL-8. J. Cell Biol. 117:565-572.

49. Le-Gouvello, S., E. Vivier, P. Debre, Y. Thomas, and O. Colard. 1992. CD2 triggering stimulates the formation of platelet-activating factor-acether from alkyl-arachidonoyl-glycerophosphocholine in a human $\mathrm{CD}^{+} \mathrm{T}$ lymphocyte clone. J. Immunol. 149:1289-1293.

50. Honda, Z., M. Nakamura, I. Miki, M. Minami, T. Watanabe, Y. Seyama, H. Okado, H. Toh, K. Ito, T. Myamoto, and T. Shimizu. 1991. Cloning by functional expression of platelet activating factor receptor from guinea pig lung. Nature (Lond.). 349:342-346.

51. Ye, R. D., E. R. Prossitz, A. Zuo, and C. G. Cochrane. 1991. Characterisation of a human cDNA that encodes a functional receptor for platelet activating factor. Biochem. Biophys. Res. Commun. 180:105-111.

52. Schwertschlag, U. S., and A. R. Whorton. 1988. Platelet activating factor induced homologous and heterologous desensitization in cultured vascular smooth muscle cells. J. Biol. Chem. 263:13791-13796.

53. Bussolino, F., G. Camussi, M. Aglietta, P. Braquet, A. Bosia, G. Pescarmona, F. Sanavio, N. D'Urso, and P. C. Marchisio. 1987. Endothelial cells are targets for platelet activating factor. I. Platelet activating factor induces changes in cytoskeletal structure. J. Immunol. 139:2439-2446.

54. Brock, T. A., and M. A. Gimbrone. 1986. Platelet activating factor alters calcium homeostasis in cultured vascular endothelial cells. Am. J. Physiol. 250:H1086-H1092.

55. Bussolino, F., F. Silvagno, G. Garbarino, C. Costamagna, F. Sanavio, M Arese, R. Soldi, M. Aglietta, G. Pescarmona, G. Camussi, and A. Bosia. 1994. Human endothelial cells are targets for platelet-activating factor (PAF). Activation of $\alpha$ and $\beta$ protein kinase $C$ isozymes in endothelial cells stimulated by PAF. J. Biol. Chem. 269:2877-2886.

56. Lorant, D. E., K. D. Patel, T. M. McIntyre, R. P. McEvert, S. M. Prescott, and G. A. Zimmerman. 1991. Coexpression of GMP-140 and PAF by endothelium stimulated by histamine and thrombin: a juxtacrine mechanism for adhesion and activation of neutrophils. J. Cell Biol. 115:223-234.

57. Müller, E., P. Dagenais, N. Alami, and M. Rola-Pleszczynski. 1993. Identification and functional characterization of platelet-activating factor receptor in human leukocyte population using polyclonal anti-peptide antibody. Proc. Natl. Acad. Sci. USA. 90:5818-5822.
58. Wittek, A. E., C. D. Mitchell, G. R. Armstrong, A. Albini, G. R. Martin, R. Seeman, I. S. Levenbook, D. E. Wierenga, J. Ridge, R. C. Dunlap, et al. 1991. Propagation and properties of Kaposi's sarcoma-derived cell lines obtained from patients with AIDS: similarly of cultured cells to smooth muscle cells. AIDS (Phila.). 5:1485-1493.

59. Weich, A. W., S. Z. Salahuddin, G. Parkash, S. Nakamura, R. C. Gallo, and J. Folkman. 1991. AIDS-associated Kaposi's sarcoma-derived cells in long term culture express and synthesize smooth muscle alpha-actin. Am. J. Pathol. 139:1251-1258.

60. Bussolino, F., M. F. Di Renzo, M. Ziche, E. Bocchietto, M. Olivero, L. Naldini, G. Gaudino, L. Tamagnone, A. Coffer, and P. M. Comoglio. 1992 Hepatocyte growth factor is a potent angiogenic factor which stimulates endothelial cell motility and growth. J. Cell Biol. 119:629-641.

61. Camussi, G., F. Bussolino, G. Salvidio, and C. Baglioni. 1987. Tumor necrosis factor/cachectin stimulates peritoneal macrophages, polymorphonuclea neutrophils, and vascular endothelial cells to synthesize and release platelet activating factor. J. Exp. Med. 166:1390-1404.

62. Montrucchio, G., S. Bergerone, F. Bussolino, G. Aloatti, L. Silvestro, E Lupia, A. Cravetto, M. DiLeo, G. Emanuelli, and G. Camussi. 1993. Streptokinase induces intravascular release of platelet activating factor (PAF) in patients with acute myocardial infarction and stimulates PAF synthesis by cultured human endothelial cells. Circulation. 88:1476-1483.

63. Zigmond, S. H., and J. G. Hirsch. 1973. Leukocyte locomotion and chemotaxis: new methods for evaluation and demonstration of cell-derived chemotactic factor. J. Exp. Med. 137:387-400.

64. Passaniti, A., R. M. Taylor, R. Pili, Y. Guo, P. V. Long, J. A. Haney, R. R. Pauly, D. S. Grant, and G. R. Martin. 1992. A simple, quantitative method for assessing angiogenesis and antiangiogenesis agents using reconstituted basement membrane, heparin and fibroblast growth factor. Lab. Invest. 67:519-528.

65. Montrucchio, G., E. Lupia, E. Battaglia, F. Bussolino, G. Emanuelli, and G. Camussi. 1994. Tumor-necrosis factor $\alpha$-induced angiogenesis depends on "in situ" platelet-activating factor biosynthesis. J. Exp. Med. 180:377-382.

66. Heuer, H. O., J. Casals-Stenzel, G. Muacevic, and K. H. Weber. 1990. Pharmacologic activity of bepafant (WEB 2170), a new and selective hetrazepinoic antagonist of platelet-activating factor. J. Pharmacol. Exp. Ther. 255:962968

67. Chirwing, J., R. Przybyla, R. MacDonald, and W. Rutter. 1979. Isolation of biologically active ribonucleic acid from sources enriched in ribonuclease. Biochemistry. 18:5294-5299.

68. Breier, G., U. Albrecht, S. Sterrer, and W. Risau. 1992. Expression of vascular endothelial growth factor during embryonic angiogenesis and endothelial cell differentiation. Development (Camb.). 114:521-532.

69. Rollins, B. J., E. D. Morrison, and C. D. Stiles. 1988. Cloning and expression of JE, a gene inducible by platelet-derived growth factor and whose product has cytokine-like properties. Proc. Natl. Acad. Sci. USA. 85:3738-3742.

70. Degen, S. J., L. A. Stuart, S. Han, and C. S. Jamison. 1991. Characterization of the mouse cDNA and gene coding for a hepatocyte growth factor-like protein: expression during development. Biochemistry. 30:9781-9791.

71. Tekamp-Olson, P., C. Gallegos, D. Bauer, J. McClain, B. Sherry, M. Fabre, S. van Deventer, and A. Cerami. 1990. Cloning and characterization of cDNAs for murine macrophage inflammatory proteins and its human homologues. J. Exp. Med. 172:911-919.

72. Cochran, B. H., A. C. Raffel, and C. D. Stiles. 1983. Molecular cloning of gene sequences regulated by platelet-derived growth factor. Cell. 33:939-947.

73. Hebert, J. M., C. Basilico, M. Goldfarb, O. Haub, and G. R. Martin. 1990. Isolation of cDNAs encoding four mouse FGF family members during embryogenesis. Dev. Biol. 138:456-463.

74. More, R., G. Casey, S. Brookes, M. Dixon, G. Peters, and C. Dickson. 1986. Sequence, topography and protein coding potential of mouse int-2. A putative oncogene activated by mouse mammary tumor virus. EMBO (Eur. Mol. Biol. Organ.) J. 5:919-924.

75. Delapeyriere, O., O. Rosnet, D. Benharroch, F. Raybaud, S. Marchetto, J. Planche, F. Galland, M. G. Mattei, N. G. Copeland, N. A. Jenkins, F. Coulier, and D. Bimbaum. 1990. Structure, chromosome mapping and expression of the murine FGF-6 gene. Oncogene. 5:823-831.

76. Tessner, T., J. T. O'Flaherty, and R. L. Wykle. 1989. Stimulation of platelet-activating factor synthesis by a nonmetabolizable bioactive analog of platelet-activating factor and influence of arachidonic acid metabolites. J. Biol. Chem. 264:4794-4799.

77. Millauer, B., S. Wizigmann-Voos, H. Schnurch, R. Martinez, N. P. H. Moller, W. Risau, and A. Ulrich. 1993. High affinity VEGF binding and developmental expression suggest Flk-1 as a major regulator of vasculogenesis and angiogenesis. Cell. 72:835-846.

78. Quinn, T. P., K. G. Peters, C. DeVries, N. Ferrara, and L. T. Willams. 1993. Fetal liver kinase 1 is a receptor for vascular endothelial growth factor and is selectively expressed in vascular endothelium. Proc. Natl. Acad. Sci. USA. 90:7533-7537. 
79. Gutterman, J. U. 1994. Cytokine therapeutics: lessons from interferon $\alpha$. Proc. Natl. Acad. Sci. USA. 91:1198-1205.

80. Aboufavia, D., D. Miles, D. Saks, and R. Mitsuyasu. 1989. Intravenous recombinant tumor necrosis factor in the treatment of AIDS-related Kaposi's sarcoma. J. Acquired Immune Defic. Syndr. 2:54-58.

81. Folkman, J., and Y. Shing. 1992. Angiogenesis. J. Biol. Chem. 267:1093110934.

82. Frater-Schroder, M., W. Risau, R. Hallaman, P. Gautschi, and P. Bohlen 1987. Tumor-necrosis factor type $\alpha$, a potent inhibitor of endothelial cell growth in vitro, is angiogenic in vivo. Proc. Natl. Acad. Sci. USA. 84:5277-5281.

83. Seeds, E. A. M., A. J. Coyle, and C. P. Page. 1991. The effect of the selective PAF antagonist WEB 2170 on PAF and antigen induced airway hyperresponsiveness and eosinophil infiltration. J. Lipid Med. 4:111-121.

84. Ikegami, K., C. J. Meade, H. O. Heuer, and F. Birke. 1992. Hetrazepine PAF antagonists. J. Lipid Med. 5:177-182.

85. Maglione, D., V. Guerriero, G. Viglietto, P. Delli-Bovi, and M. G. Persico. 1991. Isolation of a human placenta cDNA coding for a protein related to the vascular permeability factor. Proc. Natl. Acad. Sci. USA. 88:9267-9271.

86. Koch, A. E., P. J. Polverini, S. L. Kunkel, L. A. Harlow, L. A. Di Pietro,

V. M. Elner, S. G. Elner, and R. M. Strieter. 1992. Interleukin-8 as a macrophagederived mediator of angiogenesis. Science (Wash. DC). 258:1798-1801.

87. Berse, B., L. F. Brown, L. Van De Water, H. F. Dvorak, and D. R. Senger.

1992. Vascular permeability factor (vascular endothelial growth factor) gene is expressed differentially in normal tissues, macrophages and tumors. Mol. Cell. Biol. 3:211-219.

88. Baird, A., P. Mormede, and P. Bohlen. 1985. Immunoreactive fibroblast growth factor in cells of peritoneal exudate suggests its identity with macrophagederived growth factor. Biochem. Biophys. Res. Commun. 126:358-364.

89. Mantovani, A., B. Bottazzi, F. Colotta, S. Sozzani, and L. Ruco. 1992. The origin and function of tumor-associated macrophages. Immunol. Today. 13:265-270.

90. Rola-Pleszczynski, M., and J. Stankova. 1992. Differentiation-dependent modulation of TNF production by PAF in human HL-60 myeloid leukemia cells. J. Leukocyte Biol. 51:609-613.

91. Smith, C. S., L. Parker, and W. T. Shearer. 1994. Cytokine regulation by platelet-activating factor in a human B cell line. J. Immunol. 153:3997-4005.

92. Bazan, N. G., B. S. Fletcher, H. R. Herschman, and P. K. Mukherjee. 1994. Platelet-activating factor and retinoic acid synergistically activates the inducible prostaglandin synthase gene. Proc. Natl. Acad. Sci. USA. 91:5252-5256.

93. Smith, C. S., and W. T. Shearer. 1994. Activation of NF- $\kappa$ B and immunoglobulin expression in response to platelet-activating factor in a human $\mathrm{B}$ cell line. Cell. Immunol. 155:292-303.

94. Sciacca, F. L., M. Stürzl, F. Bussolino, M. Sironi, H. Brandstetter, C. Zietz, D. Zhou, C. Matteucci, G. Peri, S. Sozzani, et al. 1994. Expression of adhesion molecules, platelet-activating factor, and chemokines by Kaposi's sarcoma cells. J. Immunol. 153:4816-4825. 